\title{
A two-dimensional volatility basis set - Part 2: Diagnostics of organic-aerosol evolution
}

\author{
N. M. Donahue ${ }^{1}$, J. H. Kroll ${ }^{2}$, S. N. Pandis ${ }^{1,3}$, and A. L. Robinson ${ }^{1}$ \\ ${ }^{1}$ Carnegie Mellon University Center for Atmospheric Particle Studies, Pittsburgh, USA \\ ${ }^{2}$ MIT Departments of Civil and Environmental Engineering and Chemical Engineering, Cambridge, USA \\ ${ }^{3}$ Institute of Chemical Engineering and High Temperature Processes, FORTH, Patras, Greece
}

Correspondence to: N. M. Donahue (nmd@andrew.cmu.edu)

Received: 9 August 2011 - Published in Atmos. Chem. Phys. Discuss.: 5 September 2011

Revised: 20 December 2011 - Accepted: 22 December 2011 - Published: 16 January 2012

\begin{abstract}
We discuss the use of a two-dimensional volatility-oxidation space (2-D-VBS) to describe organicaerosol chemical evolution. The space is built around two coordinates, volatility and the degree of oxidation, both of which can be constrained observationally or specified for known molecules. Earlier work presented the thermodynamics of organics forming the foundation of this 2-D-VBS, allowing us to define the average composition $(\mathrm{C}, \mathrm{H}$, and $\mathrm{O})$ of organics, including organic aerosol (OA) based on volatility and oxidation state. Here we discuss how we can analyze experimental data, using the 2-D-VBS to gain fundamental insight into organic-aerosol chemistry. We first present a wellunderstood "traditional" secondary organic aerosol (SOA) system - SOA from $\alpha$-pinene + ozone, and then turn to two examples of "non-traditional" SOA formation - SOA from wood smoke and dilute diesel-engine emissions. Finally, we discuss the broader implications of this analysis.
\end{abstract}

\section{Introduction}

Organic aerosol (OA) comprises a complex system linking emissions, chemical transformations, phase partitioning and removal (Kroll and Seinfeld, 2008; Donahue et al., 2009; Hallquist et al., 2009). Until recently, OA was classified as either primary (POA) - compounds emitted directly in the condensed phase - or secondary (SOA) - condensed-phase compounds formed from volatile precursors. Those distinctions are fading as it becomes clear that the large majority of all organic compounds associated with $\mathrm{OA}$ are semi volatile (Donahue et al., 2006; Robinson et al., 2007), and that extensive oxidation chemistry pervades the system, resulting in high concentrations of oxidized OA (OOA) (Jimenez et al., 2009; Kroll et al., 2011).

When a gas-phase organic precursor is oxidized in the atmosphere it can generate reaction products with added functionality (oxygen containing substituents), higher polarity, and thus lowered vapor pressure (Pandis et al., 1992). It is widely accepted that a portion of these products partition into aerosol particles, with partial pressures controlled by the thermodynamics of the complex organic mixtures in the particles (Pankow, 1994; Pankow et al., 2001; Pankow and Asher, 2008). Historically, attention focused on relatively light, high-volatility SOA precursors, which dominate organic carbon mass emissions (Fraser et al., 1997; Griffin et al., 1999). However, much heavier, low-volatility vapors can potentially form SOA much more efficiently than the more abundant but much more volatile traditional SOA precursors (Robinson et al., 2007; Shrivastava et al., 2008; Donahue et al., 2009).

Field observations during the past decade provided consistent evidence that state-of-the-art models implementing standard SOA chemistry underpredict concentrations of ambient OOA in almost all environments, and often overpredict fresh POA concentrations. The magnitude of the OOA underprediction is debated, ranging from a factor of 10 (Volkamer et al., 2006; Goldstein and Galbally, 2007) to a factor of two (Gaydos et al., 2007), but it is clearly significant.

Furthermore, model shortfalls are not just OA levels but the degree of oxidation; models tend to favor relatively unoxidized POA (Chung and Seinfeld, 2002; Kanakidou et al., 2005) while observations indicate predominance of highly oxidized OOA (Zhang et al., 2005, 2007; Ng et al., 2010; Hildebrandt et al., 2010). Recent observations from highresolution mass spectrometers give measurements of the 
oxygen-to-carbon ratio (O:C) and hydrogen-to-carbon ratio (H:C) of this OA (Aiken et al., 2008; Ng et al., 2010), and these data can be combined to describe the mean oxidation state of carbon $\left(\overline{\mathrm{OS}}_{\mathrm{C}}\right)$ of the organic aerosol (Kroll et al., 2011). Not only is ambient OA on average much more oxidized than POA, it is often more oxidized than most SOA produced in smog-chamber experiments (Jimenez et al., 2009; Holzinger et al., 2010). Parallel field observations coupling the AMS to a long residence-time (15 s) thermodenuder also reveal that both the primary and secondary components of ambient $\mathrm{OA}$ are relatively volatile, with half of the most oxidized organic material evaporating at $125^{\circ} \mathrm{C}$, and half of other components, including less oxidized secondary components and more reduced primary components, evaporating at $80^{\circ} \mathrm{C}$ (Huffman et al., 2009; Cappa and Jimenez, 2010; Lee et al., 2011).

A challenge to our understanding of $\mathrm{OA}$ is that organic compounds - especially large ones - are very reactive in the atmosphere. Unsaturated compounds (mostly terpenoids including isoprene) react within an hour or two, but even large saturated organics have gas-phase lifetimes against $\mathrm{OH}$ reaction of five to eight hours under typical conditions, meaning that one or two generations of oxidation will typically occur in a day (Donahue et al., 2005). OH and other radicals also collide with particles, heterogeneously oxidizing the condensed-phase compounds; because of mass-transfer limitations the timescale is longer, but it is still only a few days (Moise and Rudich, 2001; Smith et al., 2003; Molina et al., 2004; Robinson et al., 2006; George et al., 2008; Kroll et al., 2009). Many oxidized organics are quite water soluble, and aqueous phase chemistry can also substantially alter OA properties and serve as an additional source of OA mass via cloud (Carlton et al., 2006; Ervens and Volkamer, 2010) or moist aerosol-phase (Ervens and Volkamer, 2010) processing.

Oxidation clearly influences OA climate effects, as organics move from being hydrophobic to hydrophilic as they gain oxygen (Cruz and Pandis, 1997, 1998; Huff Hartz et al., 2006), and hygroscopicity is related to oxidation (Jimenez et al., 2009). Oxidation could also probably influence OA health effects, though data are sparse on this topic.

We recently presented the thermodynamic underpinnings of a two-dimensional volatility space describing the coupled phase partitioning and oxygenation of organic aerosol (OA) (Donahue et al., 2011). That framework extends the onedimensional volatility basis set (1-D-VBS) presented in Donahue et al. (2006), allowing us to describe both the phase partitioning and average composition $(\mathrm{C}: \mathrm{H}: \mathrm{O})$ of compounds at various points in the space. A shortcoming of the 1-DVBS is that compounds of similar volatility (e.g. triccosane and levoglucosan) can have very different properties and reactivities. OA is chemically dynamic, evolving continuously via multiphase oxidation reactions (Rudich et al., 2007; Hallquist et al., 2009), and consequently the shortcomings of the 1-D VBS make it difficult to describe OA evolution consistently.

In this work we shall use the 2-D volatility-oxidation space in a diagnostic mode, discussing ambient observations and laboratory experiments to infer important features about the chemical processes driving OA evolution. In a subsequent paper we shall present the prognostic 2-D-VBS and apply it to a series of case studies, constrained by laboratory data, to explore the role of photochemical oxidation on organic aerosol properties.

Recent work has also shown that while submicron aerosol particles "should" equilibrate quickly (Marcolli et al., 2004), mass-transfer limitations may impede the approach to equilibrium. Both diffusion limitations within particles forming amorphous, viscous, glassy solids (Zobrist et al., 2008; Virtanen et al., 2010; Vaden et al., 2011) and suppression in the apparent mass accommodation coefficient (Stanier et al., 2007; Grieshop et al., 2007, 2009c; Cappa and Jimenez, 2010; Riipinen et al., 2010) have been discussed, though these could well be manifestations of the same fundamental phenomenon. Depending on the timescale of an experiment and the extent to which conditions depart from the equilibrium state, these dynamical effects can complicate the interpretation of experiments (and be important in the atmosphere). However, they do not fundamentally alter the underlying thermodynamics. In particular, there is a misperception that partitioning models assume liquid particles. They do not. Instead, the sub-cooled liquid vapor pressure is presumed to be indicative of the free energy for any amorphous mixture (Pankow, 1994). We have not observed evidence of disequilibration during aerosol growth experiments conducted over hours in smog chambers (once chemistry is stopped, particles stop growing) and so in this discussion we shall present an equilibrium interpretation.

\section{Two dimensions}

Our two-dimensional space, shown in Fig. 1a, uses volatility (saturation concentration, $C^{*}$, in $\mu \mathrm{g} \mathrm{m}^{-3}$ ) as the $\mathrm{x}$ coordinate and the extent of oxidation as the y coordinate. In previous publications we have used the oxygen to carbon ratio $(\mathrm{O}: \mathrm{C})$ as a measure of the extent of oxidation (Jimenez et al., 2009; Donahue et al., 2011). Here we use the average oxidation state of carbon $\left(\overline{\mathrm{OS}}_{\mathrm{C}}\right)$ as the principal y-axis (Kroll et al., 2011). As a practical matter, "oxygenation" (O:C) and "oxidation" $\left(\overline{\mathrm{OS}}_{\mathrm{C}}\right)$ are highly correlated (Heald et al., 2010$)$, allowing us to use them almost interchangeably. This work complements recent work by Kroll et al. (2011), who presented the $\overline{\mathrm{OS}}_{\mathrm{C}}$ coordinate to describe progressive oxidation chemistry, with the organic carbon number as a second dimension.

We choose $C^{*}$ and $\overline{\mathrm{OS}}_{\mathrm{C}}$ as two complementary coordinates because they explicitly track properties that we can observe in experiments and in the atmosphere and that we need to know to accurately model OA behavior. Oxidation state 

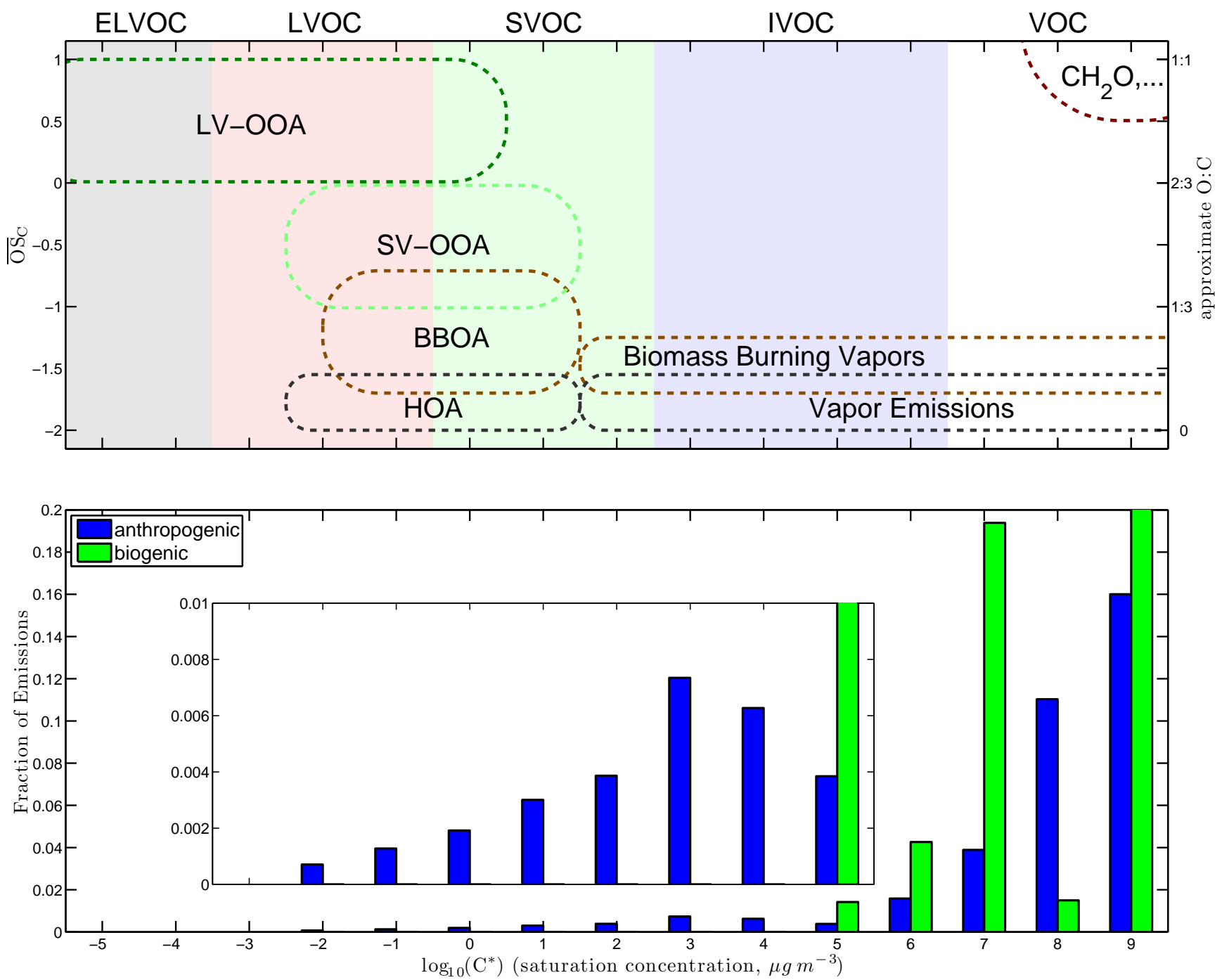

Fig. 1. (a) Volatility $\left(C^{*}\right.$ in $\left.\mu \mathrm{g} \mathrm{m}^{-3}\right)$ and oxidation state $\left(\overline{\mathrm{OS}}_{\mathrm{C}}\right)$ for important atmospheric organics. Note the enormous range on the (logarithmic) x-axis. The volatility ranges described in the text are indicated by colored bands: aerosols are located in the ELVOC (gray), LVOC (red) and SVOC (green) range. Factors based on ambient aerosol-mass-spectrometer (AMS) observations are shown to the left, in the condensed-phase region. The $\overline{\mathrm{OS}}_{\mathrm{C}}$ of ambient aerosol is constrained by high-resolution AMS measurements, while the volatility is constrained by thermodenuder measurements. Oxidation chemistry drives organic material monotonically upwards in this space, toward ultimate (volatile) products $\mathrm{CH}_{2} \mathrm{O}$, shown in the upper right, and $\mathrm{CO}$ and $\mathrm{CO}_{2}$ at $\overline{\mathrm{OS}}_{\mathrm{C}}=2$ and 4 . Ranges for primary emissions are shown as bands along the low $\overline{\mathrm{OS}}_{\mathrm{C}}$ region of the space. (b) Emissions vs. volatility in the continental United States. Fluxes are shown for anthropogenic (pyrogenic) and biogenic emissions, as a fraction of total emissions. Emissions are very heavily weighted toward the volatile end of the range - the primary OA AMS factors (HOA and BBOA) represent the lowest-volatility tails of the pyrogenic flux distributions. The inset magnifies the lower volatility emissions for clarity.

can now be directly measured by Aerosol Mass Spectrometry even when few of the constituent species are measured or even identified individually (Canagaratna et al., 2007; Kroll et al., 2011). Volatility can be constrained with a number of techniques, with varying degrees of certainty as discussed below.
The dimensions in our 2-D space are theoretically grounded and empirically observable. The descriptive version of the 2-D space described in Donahue et al. (2011) is built on the pure-component volatility $C^{o}$, from which mixing properties (gas-aerosol partitioning and condensed-phase activity coefficients) are described. The diagnostic version presented here is empirical, with observed volatility $C^{*}$ over whatever mixture exists. Pure-component volatilities $\left(C_{i}^{o}\right)$ 
and volatilities in a mixture $\left(C_{i, s}^{*}\right)$ are related via the activity coefficient: $C_{i, s}^{*}=\gamma_{i, s} C_{i}^{o}$. This is discussed in detail in Donahue et al. (2011).

Our starting point is that we do not know molecular structures or even carbon number for $O A$. This is certainly true in the atmosphere but frequently so even in chamber experiments. That is in contrast to two other 2-D spaces proposed recently, which have different objectives and strengths. The carbon-number polarity grid of Pankow and Barsanti (2009) is designed to understand and predict the relationship between carbon number, polarity, and volatility, while the carbon-number $\overline{\mathrm{OS}}_{\mathrm{C}}$ space of Kroll et al. (2011) is designed to understand the evolution of carbon number during oxidative processes in the atmosphere. While frameworks built on the specific molecular structure of organic constituents have obvious fundamental appeal, they are only lightly constrained by observations; their power is in predicting phase partitioning for mechanisms that explicitly track molecular structure. In contrast, we know the mean oxidation state of OA samples, we know the OA levels, and we can gain a very good idea of the volatility distribution. The ansatz of our framework is that we know the OA properties far better than the specific constituents, and we thus propose a space based on those properties. This space is thus almost an inverse of the other spaces. When we discretize the space into a 2-DVBS, our hypothesis is that the resulting "bins" will contain a collection of molecules with similar properties (specifically $C^{*}$ and $\overline{\mathrm{OS}}_{\mathrm{C}}$ ). We will indeed seek to identify some of the molecules in those bins, but it is the properties that define the bins.

\subsection{X-axis: volatility}

Our principal axis is volatility, expressed empirically as effective saturation concentration, $C^{*}$, in $\mu \mathrm{g} \mathrm{m}^{-3}$ on a logarithmic coordinate. $C^{*}$ determines the amount of OA $\left(C_{\mathrm{OA}}\right)$. The phase partitioning of a compound $i$, meaning its fraction in the condensed phase, is given by (Donahue et al., 2006, 2011):

$\xi_{i}=\left(1+\frac{C_{i}^{*}}{C_{\mathrm{OA}}}\right)^{-1} ; \quad C_{\mathrm{OA}}=\sum_{i} C_{i} \xi_{i}$

where $C_{i}^{*}$ is the condensed-phase mass concentration at which $50 \%$ of compound $i$ is in the condensed phase $\left(C_{i}^{*}=\right.$ $C_{\mathrm{OA}}$ when $\xi_{i}=0.5$ ). The total concentration $C_{\mathrm{OA}}$ is in turn the sum of the condensed-phase concentrations of all compounds forming the condensed-phase mixture, so Eqs. (1) must be solved iteratively.

The temperature dependence of $C_{i}^{o}$ is given by the Clausius-Clapeyron equation, which we can approximate as (Donahue et al., 2006; Epstein et al., 2010):

$\ln C_{i}^{o}(T) \simeq \ln C_{i}^{o}(300 \mathrm{~K})+\left[\frac{\Delta H_{i}^{\text {vap }}}{R}\left(\frac{1}{300 \mathrm{~K}}-\frac{1}{T}\right)\right]$
For lumped approaches such as the VBS, $i$ is an index for a discrete bin in the 1-D or 2-D space.

Potentially as important as these equilibrium expressions, the mass-transfer rate of a compound $i$ from the condensed phase to the gas phase will be governed by $C_{i}^{*}$. A combination of $C^{*}(300), \Delta H^{\text {vap }}$ and the accommodation (evaporation) coefficient plays a controlling role in thermodenuders (Riipinen et al., 2010; Cappa and Jimenez, 2010). Mass transfer may also be limited by diffusion in the particle phase, as there is growing evidence that the highly viscous compounds typical of OA may form a glassy condensed phase (Zobrist et al., 2008; Virtanen et al., 2010). For example, the most volatile constituents typical of reduced and more oxidized OA are pentacosane and levoglucosan, both of which are self evidently highly viscous as pure compounds (Donahue et al., 2011). This may explain the need to invoke mass accommodation coefficients far below unity in some applications (Grieshop et al., 2007; Riipinen et al., 2010). However, a glassy but amorphous condensed phase in no way invalidates the fundamental basis behind the equilibrium partitioning theory presented in Eq. (1); it merely adds the (substantial) complication that the approach to equilibrium may be delayed.

\subsubsection{Measuring $C^{*}$}

Volatility cannot be measured directly for relevant systems, but it is much more readily constrained than other quantities such as carbon number. The $C^{*}$ distribution can be constrained from SOA growth (Pathak et al., 2007; Stanier et al., 2008), emissions dilution measurements (Shrivastava et al., 2008), volatility-based chromatography (Williams et al., 2010; Isaacman et al., 2011) and thermodenuder measurements (Grieshop et al., 2009c). All of these approaches have their challenges, including decoupling the chemistry from partitioning during SOA growth (Kroll and Seinfeld, 2008; Hildebrandt et al., 2009), uncertainties in mass transfer coefficients for both dilution samplers and thermodenuders (Riipinen et al., 2010; Cappa and Jimenez, 2010), and uncertain vaporization enthalpies for thermodenuders (Epstein et al., 2010; Cappa and Jimenez, 2010). A combination of these methods, however, can provide self-consistent descriptions of aerosol volatility distributions (Grieshop et al., 2007, 2009c).

The most direct method to measure $C^{*}$ from an ambient sample is volatility-based chromatography, but the relatively polar, low volatility compounds characteristic of SOA are extremely difficult to elute (Williams et al., 2010; Isaacman et al., 2011). Absent direct measurement, $C^{*}$ must be inferred.

Volatility can be inferred indirectly by driving OA out of equilibrium (e.g. changes in gas-phase concentrations or $T$ ) and observing OA responses. In almost all cases presented here, those responses are particles either growing or shrinking. It is preferable to avoid heating or cooling, 
which introduces the uncertain $\Delta H^{\text {vap }}$. There are two approaches. The simplest conceptually is isothermal dilution. If a sample is diluted from, say $C_{\mathrm{OA}}=10^{4} \mu \mathrm{g} \mathrm{m}^{-3}$ by a factor of 1000 , the constituents with $10 \leq C_{i}^{*} \leq 10^{4}$ will evaporate significantly, and particles will shrink (resulting in $C_{\mathrm{OA}}<10 \mu \mathrm{g} \mathrm{m}^{-3}$ ). Taken as a continuous function of $C_{\mathrm{OA}}$, size or mass data can readily be inverted for a $C^{*}$ distribution in volatility bins separated by a factor of 10 each (the VBS) (Donahue et al., 2006; Shrivastava et al., 2008; Grieshop et al., 2009c; Robinson et al., 2010).

The same principle applies to building up mass concentrations, including during SOA formation experiments (Odum et al., 1996; Presto and Donahue, 2006). However, for the interpretation to be straightforward it is essential that the overall (gas and particle) composition remain constant during an experiment - a highly doubtful assumption in experiments involving ongoing photochemical oxidation. Put simply, to derive volatility estimates from increasing mass yields observed following increasing precursor consumption the dominant cause must be increased formation of identical reaction products. For this reason, we have combined SOA formation and dilution experiments for $\alpha$-pinene + ozone SOA to demonstrate that the SOA volatility distributions are consistent upon formation (Presto and Donahue, 2006; Pathak et al., 2007; Shilling et al., 2008) and dilution (Grieshop et al., 2007).

Dilution is less useful as a diagnostic under most ambient conditions. This is because several orders of magnitude of dilution are required, which would eliminate virtually all of the signal. Consequently, heating in a thermodenuder is the other choice (An et al., 2007; Huffman et al., 2009; Lee et al., 2011). Thermodenuders are heated flow reactors based on shifting $C^{*}$ via Eq. (2). They are subject to uncertainties in $\Delta H^{\text {vap }}$ (Epstein et al., 2010; Cappa and Jimenez, 2010) as well as evaporation kinetics (Riipinen et al., 2010). For example, two recent publications using long residence time thermodenuders agree qualitatively but not quantitatively when sampling $\alpha$-pinene + ozone SOA in a smog chamber (An et al., 2007; Huffman et al., 2009). An additional issue is whether heating in thermodenuders promotes reactions in the OA. However, recognizing these uncertainties thermodenuder data can be inverted to obtain a volatility distribution and thus to place samples in our volatility space (Cappa and Jimenez, 2010; Lee et al., 2011).

\subsection{Y-axis: oxidation}

Our second axis is the mean oxidation state of carbon: $\overline{\mathrm{OS}}_{\mathrm{C}}$. In contrast to the principal axis, $\overline{\mathrm{OS}}_{\mathrm{C}}$ can be directly constrained even for bulk, unspeciated aerosol. Specifically, it is possible to measure the important atomic molar ratios $\mathrm{O}: \mathrm{C}$ and $\mathrm{H}: \mathrm{C}$, and infer $\overline{\mathrm{OS}}_{\mathrm{C}} \simeq 2 \mathrm{O}: \mathrm{C}-\mathrm{H}: \mathrm{C}$ (Kroll et al., 2011).

We prefer $\overline{\mathrm{OS}}_{\mathrm{C}}$ rather than either O:C or $\mathrm{H}: \mathrm{C}$ individually (O:C has been discussed previously by Jimenez et al., 2009) because oxidation reactions will invariably lead to increas- ing $\overline{\mathrm{OS}}_{\mathrm{C}}$. As a consequence, we expect trajectories in our 2-D space describing evolution in the atmosphere to have a monotonic increase in $\overline{\mathrm{OS}}_{\mathrm{C}}$. The formal definition of $\overline{\mathrm{OS}}_{\mathrm{C}}$ applies to the mean oxidation state of carbon atoms in a single molecule (Kroll et al., 2011), but the definition extends to the bulk aerosol. The only difference is that for a single molecule there is an exact, single value of $\overline{\mathrm{OS}}_{\mathrm{C}}$ (the average refers to the average oxidation state of carbon atoms within a single molecule), while for a bulk sample (on a single particle or an ensemble, but over many different molecules) there will be an average $\overline{\mathrm{OS}}_{\mathrm{C}}$ (technically $\overline{\overline{\mathrm{OS}}}_{\mathrm{C}}$ ) but also a distribution of values about that average. This is not much different than $C^{*}$, which has a single value for individual molecules and a distribution for mixtures.

\subsubsection{Measuring $\overline{\mathrm{OS}}_{\mathrm{C}}$}

The Aerodyne AMS now uses a high-resolution time-offlight (HR-ToF) mass spectrometer with a mass resolution of about 5000 (Canagaratna et al., 2007), which is sufficient to directly measure $\mathrm{O}: \mathrm{C}$ and $\mathrm{H}: \mathrm{C}$ of $\mathrm{OA}$ samples. One can also estimate these ratios from unit mass resolution AMS samples (Aiken et al., 2008). A van Krevelen analysis of HR-AMS data finds a ubiquitous average relation $\mathrm{H}: \mathrm{C}$ $\simeq 2-\mathrm{O}: \mathrm{C}$ (Heald et al., 2010), yielding an average relation $\overline{\mathrm{OS}}_{\mathrm{C}} \simeq 3 \mathrm{O}: \mathrm{C}-2$ for OA samples. Therefore, one can estimate $\overline{\mathrm{OS}}_{\mathrm{C}}$ from unit mass resolution AMS data (with significant uncertainty), even when direct $\mathrm{C}: \mathrm{H}: \mathrm{O}$ measurements are unavailable. It is important to note that bulk measurements of $\overline{\mathrm{OS}}_{\mathrm{C}}$ (or $\mathrm{OM} / \mathrm{OC}$ ) are average properties, and that individual constituents can have very different values. Also, the formal $\overline{\mathrm{OS}}_{\mathrm{C}}$ is only approximated by 2O:C-H:C (Kroll et al., 2011), which in turn is only approximately measured by even the HR-AMS (Aiken et al., 2008). However, the empirical version of the 2-D-VBS permits us to define the y-axis as 2O:C-H:C as measured by the AMS but we can simultaneously plot individual molecules with their formal $\overline{\mathrm{OS}}_{\mathrm{C}}$ when those are known.

\subsection{Dimensions and properties}

An important hypothesis behind the 2-D-VBS is that important aerosol properties can be described by these two dimensions. Volatility is a given - it is one of the coordinates. The relationship between specific molecular $C^{o}$ and the largely empirical $C^{*}$ is inexact but nonetheless useful, especially given the wide dynamic range of the space. If two dimensions are sufficient, then at a minimum the average relationship between oxidation and oxygenation $\left(\overline{\mathrm{OS}}_{\mathrm{C}}\right.$ and $\left.\mathrm{O}: \mathrm{C}\right)$ discussed above must also generally hold true - that addresses general bulk composition. Because of this, we shall generally show $\overline{\mathrm{OS}}_{\mathrm{C}}$ with $\mathrm{O}: \mathrm{C}$ on a secondary $\mathrm{y}$-axis in subsequent 2-D plots.

Any given point in this 2-D space represents many, many molecules. However, our conjecture is that 
important properties of these molecules, such as carbon number, hydrophilicity, dipole moment, and reactivity, are similar enough that their average behaves meaningfully. Consequently, the 2-D oxidation-volatility grouping is a highly useful lumping scheme for diagnosing OA behavior and modeling the atmosphere. Individual molecules can be located precisely in the space, and trajectories associated with reaction sequences are very informative about the OA life cycle. Using group-contribution relations for volatility (Pankow and Asher, 2008) we developed a descriptive version of this 2-D space in Donahue et al. (2011); this allows us to describe the average composition $(\mathrm{C}: \mathrm{H}: \mathrm{O})$ at any point in the 2-D space. We can accommodate nitrogen by tracking parallel spaces with specific nitrogen numbers, but for simplicity we are leaving $\mathrm{N}$ out of this discussion (we are effectively considering low- $\mathrm{NO}_{\mathrm{x}}$ conditions). Once we can locate molecules, even roughly, in the 2-D space, we will be able to consider trajectories in this space defined by reaction sequences (Kroll et al., 2011). Finally, the discretized version of this space remains relatively compact and thus suitable for implementation in large-scale chemical transport models. A first implementation has already been reported (Murphy et al., 2011), and full details will be described in a forthcoming manuscript.

\section{Ambient organics and the 2-D VBS}

Our next objective is to assess where ambient OA lies in the 2-D-VBS.

\subsection{Volatility classes of organics}

To simplify discussion of different classes of organics, we shall refer to a number of volatility ranges, some of which we have defined previously (Donahue et al., 2009). In most figures these ranges are identified with colored bands. Range limits are $3 \times 10^{n}$ because volatility bins are centered on powers of 10 (i.e. $0.3-3.0$, etc). In order of increasing volatility, we have:

- Extremely low volatility organic compounds (ELVOC, gray shading, $C^{*}<3 \times 10^{-4} \mu \mathrm{g} \mathrm{m}^{-3}$ ). ELVOC are almost entirely in the particle phase under any ambient conditions, but they can evaporate in a thermodenuder.

- Low volatility organic compounds (LVOC, light red shading, $3 \times 10^{-4}<C^{*}<0.3 \mu \mathrm{g} \mathrm{m}^{-3}$ ). These are predominantly in the particle phase in the atmosphere.

- Semi-volatile organic compounds (SVOC, light green shading, $0.3<C^{*}<300 \mu \mathrm{g} \mathrm{m}^{-3}$ ). Depending on ambient conditions, these compounds can be in either phase but often have sizable mass fractions in both. Note that this definition of "semi-volatile" includes much lower vapor pressures than those commonly viewed as semivolatile (Shrivastava et al., 2008): SVOCs have vapor pressures ranging from $10^{-5}-10^{-8}$ torr. The difference between common perception and this aerosol-specific definition of semi-volatile can be a source of confusion.

- Intermediate volatility organic compounds (IVOC, light blue shading, $300<C^{*}<3 \times 10^{6} \mu \mathrm{g} \mathrm{m}^{-3}$ ). Myriad compounds of quite low vapor pressure that none-theless reside almost exclusively in the gas phase under atmospheric conditions (Robinson et al., 2007; Donahue et al., 2009). Compounds often described as "semivolatile" in non-atmospheric contexts lie near the high end of the IVOC range.

- Volatile organic compounds (VOC, no shading, $C^{*}>$ $\left.3 \times 10^{6} \mu \mathrm{g} \mathrm{m}^{-3}\right)$. VOCs are always represented in models either explicitly or as lumped species; we include them for completeness, because they can be important SOA precursors, and because the VOC part of the 2-D space is useful for diagnostics, as we shall illustrate below.

All of the ranges encompass thousands of individual compounds, with complexity increasing as $C^{*}$ decreases (Goldstein and Galbally, 2007; Kroll et al., 2011), and one objective of this work is to provide a sensible classification scheme to group and understand the atmospheric transformations of these compounds.

\subsection{Empirical placement of ambient organics}

Placing ambient OA and emissions data in the 2-D-VBS provides substantial insight into the dynamic evolution of atmospheric organics.

\subsubsection{Ambient data}

OA data from ambient AMS observations tend to group into a few characteristic components, or factors (Zhang et al., 2005; Lanz et al., 2007; Ulbrich et al., 2009). These factors can be placed in this 2-D space by combining the explicit measurement of $\overline{\mathrm{OS}}_{\mathrm{C}}$ (Aiken et al., 2008; Heald et al., 2010; Kroll et al., 2011) with thermodenuder-based constraints on volatility (An et al., 2007; Huffman et al., 2009; Cappa and Jimenez, 2010). While the exact number of factors and their exact appearance (mass spectra) remains a topic of research (Ng et al., 2010), the features common to most studies include a factor resembling motor-oil or diesel emissions commonly called Hydrocarbon-like Organic Aerosol (HOA), a factor associated with biomass-burning emissions (BBOA) and one or two oxidized factors, both called Oxidized Organic Aerosol (OOA), with SV-OOA appearing to be less oxidized and more volatile and LV-OOA appearing to be more oxidized and less volatile (Jimenez et al., 2009). The most notable feature in the mass spectra representing these factors is the successive importance of an alkyl fragment, $\mathrm{C}_{4} \mathrm{H}_{9}^{+}$at $m / z=57$ for HOA, a carbonyl fragment, $\mathrm{C}_{2} \mathrm{H}_{3} \mathrm{O}^{+} \mathrm{m} / z=43$ for SV-OOA, and a carbon dioxide cation $\mathrm{CO}_{2}^{+} \mathrm{m} / z=44$ for 
LV-OOA. BBOA tends to be intermediate between HOA and LV-OOA and can be very difficult to isolate unless a substantial fragment associated with levoglucosan is present at $m / z=60\left(\mathrm{C}_{2} \mathrm{H}_{4} \mathrm{O}_{2}^{+}\right)$. The principal characteristic separating these factors is thus oxidation state. The factors separate cleanly, with $\overline{\mathrm{OS}}_{\mathrm{C}}(\mathrm{O}: \mathrm{C})$ of $-2.0--1.5(0-0.17)$ for HOA, $-1.75--0.75(0.07-0.42)$ for BBOA, $-1.0-0.0(0.33-0.67)$ for SV-OOA and 0.0-1.0 (0.67-1.00) for LV-OOA (Aiken et al., 2008; Kroll et al., 2011). This tightly constrains the $\mathrm{y}$-axis location of these factors in the 2-D volatility space.

Thermodenuder measurements from both Mexico City and the Los Angeles area reveal a consistent pattern of volatility in the four AMS OA factors described above (Huffman et al., 2009). Broadly, all of the factors are fairly volatile, with significant evaporation at modest temperatures and $50 \%$ evaporation between 75 and $125^{\circ} \mathrm{C}$. The highly oxidized LV-OOA factor is the most refractory, with $50 \%$ remaining at $125^{\circ} \mathrm{C}$, while the other three factors are more or less equally volatile, with $50 \%$ remaining at $75-85^{\circ} \mathrm{C}$. While this immediately indicates that much of the organic mass in all of these factors can not be located too far from the LVOC region in our 2-D space, precisely locating the factors remains challenging.

The key features of urban OA factors (Huffman et al., 2009) are that the first three factors, HOA, BBOA, and SVOOA (OOA-2 in Huffman) all have thermograms showing the onset of evaporation immediately upon warming from ambient temperature at a rate of about $1 \% \mathrm{~K}^{-1}$, while the LV-OOA thermogram (OOA-1 in Huffman) is initially almost flat and then shows much more gradual evaporation. Because the thermograms for the first three factors span more than $100 \mathrm{~K}$, we assume that compounds constituting these factors are distributed over 4 to $5 C^{*}$ bins, starting at 100 $\mu \mathrm{g} \mathrm{m}^{-3}$ or so. The LV-OOA factor appears to be even more broadly spread out.

One recent VBS model of ambient thermograms finds the bulk of material in the HOA, BBOA, and SV-OOA factors at roughly $0.01 \mathrm{\mu g} \mathrm{m}^{-3}$ or higher, while LV-OOA is considerably less volatile (Cappa and Jimenez, 2010). A second model treatment of highly processed OA from Crete suggests that LV-OOA may also be mostly found with $C^{*}>$ $0.01 \mu \mathrm{g} \mathrm{m}^{-3}$ (Lee et al., 2010a). Whether these differences reflect differences among thermodenuders, variations in ambient OA properties, or differences in interpretation has yet to be determined.

Figure 1a locates the AMS factors in our 2-D space. The ovals locating the factors in this figure are not meant to be limits but rather to roughly indicate a contour that includes approximately $50 \%$ of the material responsible for each factor in the AMS. We have also not yet made any effort to tilt these ovals to show any correlation between $C^{*}$ and $\overline{\mathrm{OS}}_{\mathrm{C}}$ within the factors. Figure 1a also indicates the locations of most primary emissions, which are generally quite reduced $\left(\overline{\mathrm{OS}}_{\mathrm{C}} \leq-1\right.$ or so $)$ and quite volatile.

\subsubsection{Emissions data}

Figure $1 \mathrm{~b}$ shows our best estimate of emissions into the continental United States, as discussed in Donahue et al. (2009). Here anthropogenic (blue) and biogenic (green) emissions are separated, but each is very heavily weighted toward the VOC end of the volatility range. The anthropogenic emissions are largely pyrogenic - they involve elevated temperatures - while the biogenic emissions occur near ambient temperatures. For this reason the anthropogenic emissions surpass the biogenic emissions for $C^{*} \lesssim 10^{5} \mu \mathrm{g} \mathrm{m}^{-3}$, and there is every reason to believe that the "primary" AMS factors HOA and BBOA - simply represent the lowest volatility tail of these primary emission distributions. We note that while the emissions in Fig. 1b include some biomass burning listed in the US national emissions inventory (NEI), there is in all probability a missing component roughly filling the range indicated by "Biomass Burning Vapors" not in the inventory. The vapors and OA for hydrocarbons and biomass burning emissions are shown as distinct loci in Fig. 1a only to emphasize that they happen to reside in different phases under ambient conditions.

\subsubsection{Secondary organics}

The "secondary" AMS factors - SV-OOA and LV-OOA - are not consistent with known primary emissions sources. They are much more oxidized than most known emissions. Even though their exact locations in Fig. 1 are uncertain, they still define a target for proposed mechanisms, and the target is not necessarily easy to reach in models. Because emissions are largely reduced and predominantly volatile, the chemistry forming SV-OOA and most notably LV-OOA must involve substantial oxidation combined with decreases in volatility.

A final constraint is shown in the upper right-hand corner of Fig. 1a; oxidation chemistry will produce highly oxidized small organics $-\mathrm{CH}_{2} \mathrm{O}$, $\mathrm{CO}$, and ultimately $\mathrm{CO}_{2}$, if given sufficient time (Kroll et al., 2011). Chemical reaction sequences will trace out trajectories in this space - defining those trajectories is one of the objectives of this paper - but all trajectories must eventually veer toward the upper right in our 2-D space because of the thermodynamic imperative to produce $\mathrm{CO}_{2}$.

\section{Secondary organic aerosol}

We know roughly where the SV-OOA and LV-OOA factors fall in our 2-D space, even though the exact $\mathrm{C}, \mathrm{H}$, and $\mathrm{O}$ numbers are uncertain. The next question is, how are they formed and what are the important precursors? One thing we know is that oxidation must be involved. Based on the thermodynamics developed in Pankow and Asher (2008) and Donahue et al. (2011), it is likely that many OOA molecules contain $5-12$ carbon atoms. If the number of carbon atoms $\left(n_{\mathrm{C}}\right)$ in the carbon backbone does not change during this oxidation, 
products will tend to form along lines of constant $n_{\mathrm{C}}-$ diagonal lines extending from the lower right to upper left in the 2-D-VBS (Donahue et al., 2011).

One way to form LV-OOA and SV-OOA containing $\mathrm{C}_{5}-$ $\mathrm{C}_{12}$ oxidized organics is to start with $\mathrm{C}_{5}-\mathrm{C}_{12}$ precursors and simply oxidize them, moving approximately along the carbon isopleths (conserving $n_{\mathrm{C}}$ ), starting in the lower-right VOC region and progressing diagonally upward toward the upper-left OOA region. Without question this occurs. It is traditional SOA formation (at least in the 1st generation of oxidation), and the precursors that have dominated experimental studies - isoprene, monoterpenes, alkyl-benzenes - fall exactly in this range (Kroll and Seinfeld, 2008). A second way is to start with larger precursors that then fragment, once again producing $\mathrm{C}_{5}-\mathrm{C}_{12}$ oxidized organics in the LV-OOA range (Robinson et al., 2007). A third way is to start with small precursors, form small, reactive OVOCs, and then create higher carbon number association products (oligomers) from those monomers (Kalberer et al., 2004; Volkamer et al., 2007).

\subsection{SOA formation from VOC}

As an example of traditional SOA formation, in Figs. 2, 3 and 4 , we analyze the formation of SOA in the laboratory from the $\alpha$-pinene + ozone reaction under low- $\mathrm{NO}_{\mathrm{x}}$ conditions with butanol present to scavenge $\mathrm{OH}$ radicals. This reaction is a "simple" system where we assume that a uniform distribution of products is generated as the $\alpha$-pinene is oxidized at its lone double bond (Shilling et al., 2008). There are two constraints to the 2-D product distribution. One is the systematic increase in aerosol mass yields with increasing $C_{\mathrm{OA}}$, illustrated in Fig. 2a (Presto and Donahue, 2006; Pathak et al., 2007; Shilling et al., 2008; Kroll and Seinfeld, 2008) and driven by Eq. (1). The other constraint is the systematic decrease in oxidation state with increasing $C_{\mathrm{OA}}$. This is widely reported for terpene + ozone reactions (Zhang et al., 2006; Grieshop et al., 2007; Shilling et al., 2009), and illustrated in Fig. 2b with HR-AMS data from Shilling et al. (2009) for $\alpha$-pinene + ozone. Dilution experiments show that SOA formed from this reaction evaporates as expected, with a corresponding increase in $\overline{\mathrm{OS}}_{\mathrm{C}}$, confirming that many of the SOA products are semi-volatile (Grieshop et al., 2007).

We assume that the overall (particle + gas-phase) product distribution remains the same in these experiments. If this is so, the changes in Fig. 2 are driven by partitioning. The figures are thus best read from left to right. The very low mass yields for $C_{\mathrm{OA}}<1 \mu \mathrm{g} \mathrm{m}^{-3}$ indicate very low yields for products with $C^{*}$ below this value. Mass yields for $C^{*} \simeq 1 \mu \mathrm{g} \mathrm{m}^{-3}$ are near 0.05 ; only half is in the condensed phase, so the aerosol mass yield is 0.025 (Presto and Donahue, 2006). The bulk $\overline{\mathrm{OS}}_{\mathrm{C}}$ for $C^{*} \simeq 1 \mu \mathrm{g} \mathrm{m}^{-3}$ is near -0.5 (Shilling et al., 2009). As $C_{\mathrm{OA}}$ rises, the initial SOA with high $\overline{\mathrm{OS}}_{\mathrm{C}}$, low volatility, but also quite low concentrations is overwhelmed by more abundant and more volatile com-
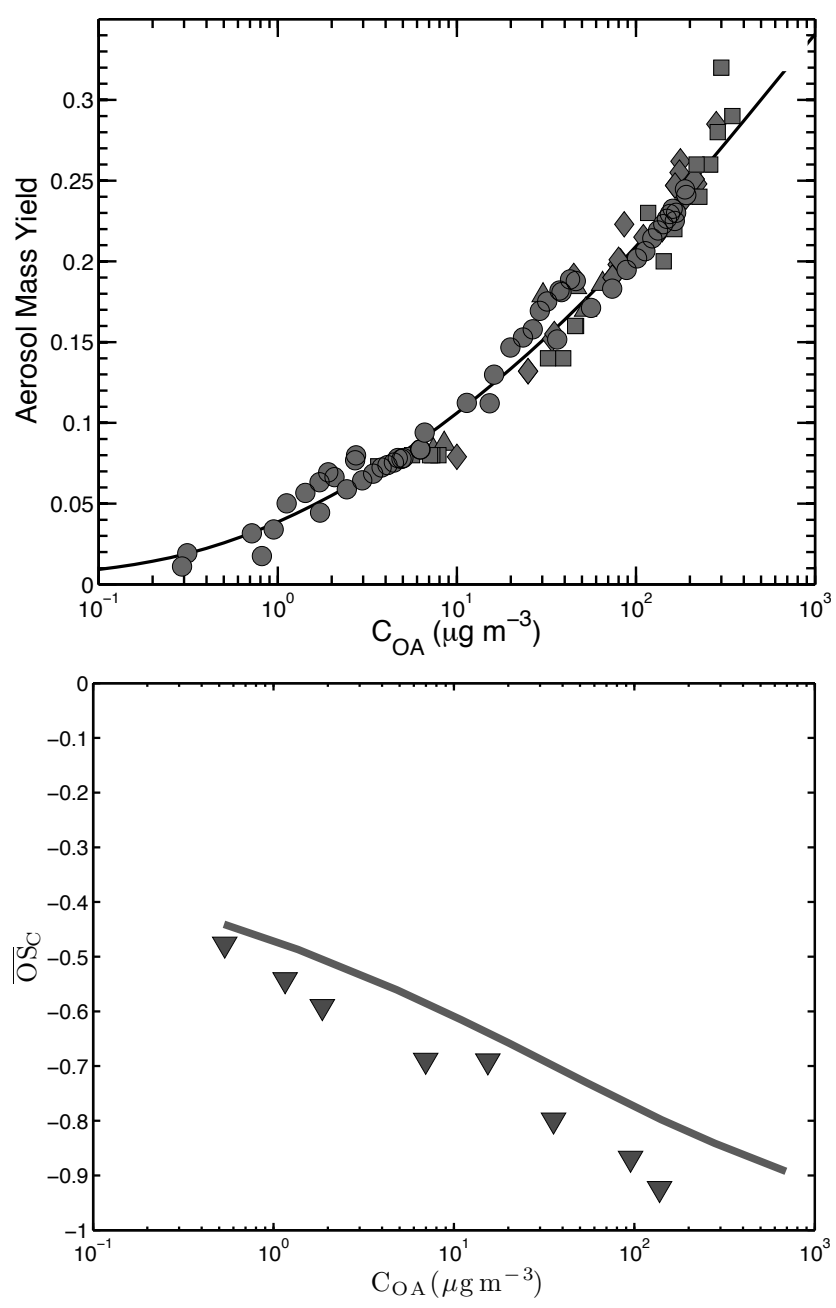

Fig. 2. (a) SOA mass yields (Presto and Donahue, 2006)) and (b) average oxidation state of carbon $\left(\overline{\mathrm{OS}}_{\mathrm{C}}\right)$ (Shilling et al., 2009)) from $\alpha$-pinene $+\mathrm{O}_{3}$, both plotted vs. SOA mass $\left(\mathrm{C}_{\mathrm{OA}}\right)$. SOA mass yields are used to fit the 1-D-VBS product distribution and $\overline{\mathrm{OS}}_{\mathrm{C}}$ constrains the product oxidation state. Partitioning predictions are shown as curves.

pounds having progressively lower $\overline{\mathrm{OS}}_{\mathrm{C}}$, driving the bulk $\overline{\mathrm{OS}}_{\mathrm{C}}$ lower.

The overall VBS product distributions inferred from experiments are shown in Fig. 3, in two dimensions in the top panel and one dimension below. We infer the yields of more volatile products with $C^{*} \geq 10^{4} \mu \mathrm{g} \mathrm{m}^{-3}$ to close the carbon mass balance. The volatility distribution of the products is based on earlier SOA mass yield fitting in Presto and Donahue (2006), augmented to conserve carbon by Donahue et al. (2009).

Determination of $\overline{\mathrm{OS}}_{\mathrm{C}}$ is not so straightforward. The total carbon yields in each $C^{*}$ column is constrained, but these can be distributed in $\overline{\mathrm{OS}}_{\mathrm{C}}$ space. Again we work from left to right. We start with an average $\overline{\mathrm{OS}}_{\mathrm{C}} \simeq-0.1$ at $C^{*}=$ 

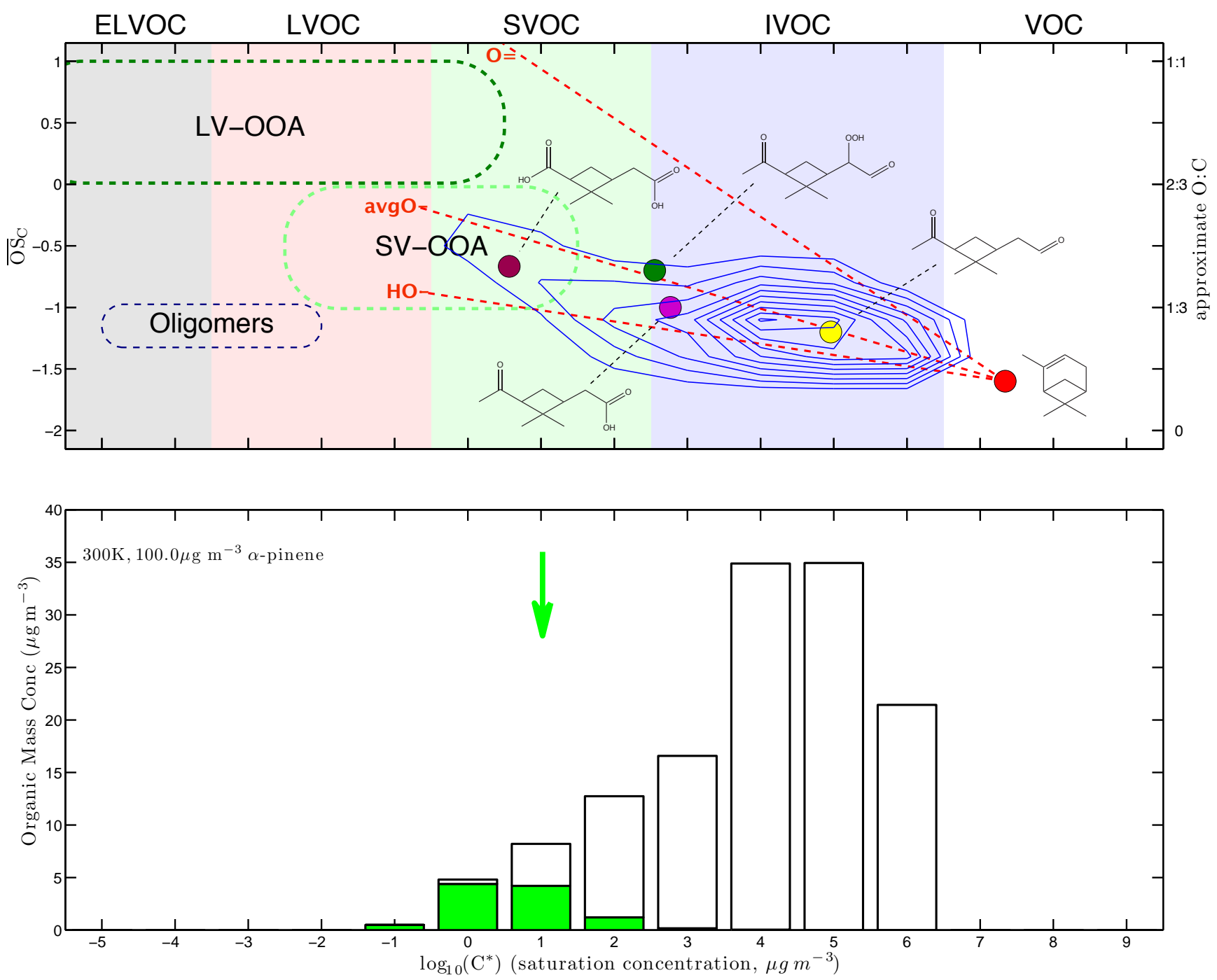

Fig. 3. Products from the ozone $+\alpha$-pinene reaction in one and two dimensions. (a) The product mass distribution is shown with blue contours. Representative 1st generation products are indicated with colored circles within the contours, along with their molecular structures. $\alpha$-Pinene is shown with a red circle. The dashed red lines extending from the $\alpha$-pinene point of origin indicate the trajectories for functionalization in this 2-D space. The middle line is near the value for organic acids and also the average value assumed for 2-D-VBS calculations. (b) A 1-D-VBS product distribution for the same SOA, given by vertical sums over $\overline{\mathrm{OS}}_{\mathrm{C}}$ for each $\log _{10} C^{*}$ bin. Partitioning is shown for $\sim 10 \mu \mathrm{g} \mathrm{m}^{-3}$ of SOA, obtained from oxidation of $100 \mu \mathrm{g} \mathrm{m}^{-3}$ of $\alpha$-pinene, with condensed-phase OA in green and vapor-phase products in white.

$0.1 \mu \mathrm{g} \mathrm{m}^{-3}$, arbitrarily spreading the yield over two bins in $\overline{\mathrm{OS}}_{\mathrm{C}}$. Because the data indicated a steady drop in $\overline{\mathrm{OS}}_{\mathrm{C}}$ with increasing $C_{\mathrm{OA}}$, the carbon yields are distributed in less oxidized bins for more volatile products. While a least-squares fit could constrain the average of these $\overline{\mathrm{OS}}_{\mathrm{C}}$ values in each 2-D column, the distribution about that average is not constrained by the bulk observations. In this work we spread the products in $\overline{\mathrm{OS}}_{\mathrm{C}}$ to obtain a smooth distribution that both agreed fairly well with the bulk AMS data and also some known products.
The product distribution compares reasonably well with a recent calculation based on a master chemical mechanism simulation of the system (Chen et al., 2011). In the upper panel, the product distribution is shown by blue contours, while in the lower panel the 1-D yields (the vertical sum of the 2-D yields) are shown with green (particle) and white (gas-phase) products for $C_{\mathrm{OA}} \simeq 10 \mu \mathrm{g} \mathrm{m}^{-3}$. The distributions in both phases are also shown as histograms in Fig. 4, with colors indicating the volatility ranges described above. The histograms are the discretized product distributions required for model implementations of this SOA process, using the 

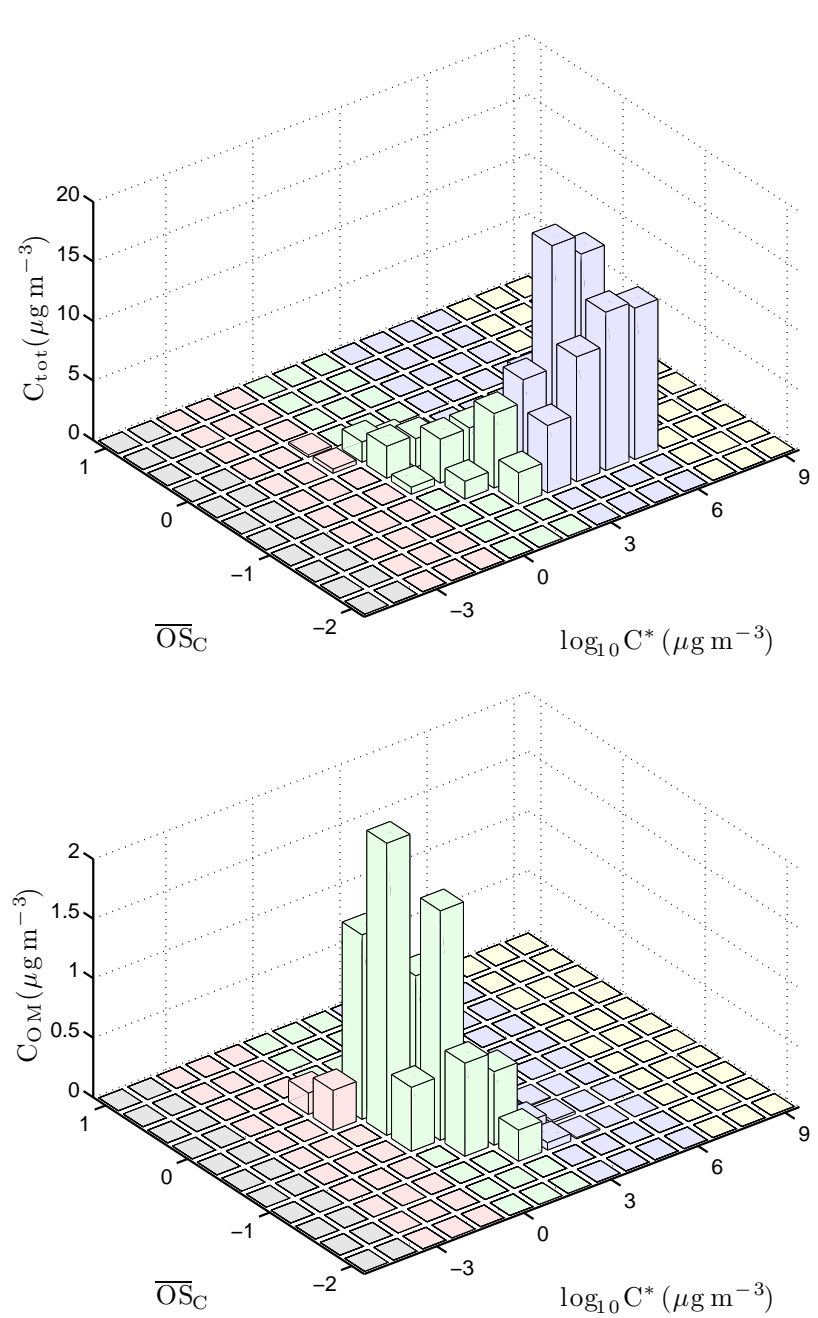

Fig. 4. Two-dimensional VBS histograms of $\alpha$-pinene $+\mathrm{O}_{3}$ products, showing total organics (top panel) and condensed-phase organics (bottom panel). The lower panel z-axis scale is a factor of 10 finer than the upper panel. Note that most SOA products are SVOCs (green) while most total products are IVOCs (blue).

volatility basis set in either one or two dimensions. Thus the distribution in Fig. 4a is the 2-D-VBS product distribution for this reaction. A matlab file with 2-D stoichiometric (carbon) yields is provided in the Supplement.

The predictions of mass yield and $\overline{\mathrm{OS}}_{\mathrm{C}}$ vs. $C_{\mathrm{OA}}$ for this distribution are also shown as curves in Fig. 2. While the $C^{*}$ (first dimension) values are constrained by the data, the $\overline{\mathrm{OS}}_{\mathrm{C}}$ distribution as a function of $C^{*}$ is not - only the bulk average value is. Note that the $y$-value $\left(\overline{\mathrm{OS}}_{\mathrm{C}}\right)$ in the 2-D-VBS is the average oxidation state of carbon in a given bin, but the overall bulk average is measured by the AMS. We thus again rely on an educated guess for a reasonable distribution in this second dimension, while keeping the average in line with observations. The range in Fig. $2 \mathrm{~b}$ is narrow, covering the middle third of the full $\overline{\mathrm{OS}}_{\mathrm{C}}$ range used in the full 2$\mathrm{D}$-VBS; consequently, the model-measurement agreement is reasonably good.

We have also plotted some observed products of the reaction with colored circles in Fig. 3a, using $C^{o}$ values predicted by the SIMPOL group-contribution method (Pankow and Asher, 2008). Pinonaldehyde (yellow circle) is the highestyield and the highest volatility major product, accounting for 20-25\% of the carbon mass (Yu et al., 1999; Jang and Kamens, 1999; Jaoui and Kamens, 2001; Saathoff et al., 2009), while cis-pinonic acid (magenta circle) and pinic acid (maroon circle) are lower yield (5-10\% of the carbon) but much lower volatility products. A potential hydroperoxide formed after $\mathrm{OH}$ elimination from a Criegee intermediate is also shown as a green circle. The product distribution shown in Fig. $3 \mathrm{~b}$ is also broadly consistent with a master chemical mechanism simulation of $\alpha$-pinene + ozone chemistry, which in turn is consistent with the mass yields shown in Fig. 2 (Chen et al., 2011). Note that, for specific molecular products the y coordinate is strictly $\overline{\mathrm{OS}}_{\mathrm{C}}$, as the average relationship between $\mathrm{O}: \mathrm{C}$ and $\overline{\mathrm{OS}}_{\mathrm{C}}\left(\mathrm{O}: \mathrm{C} \simeq 1 / 3 \overline{\mathrm{OS}}_{\mathrm{C}}+2 / 3\right)$ does not hold for individual molecules (i.e. unsaturated and thus somewhat oxidized $\alpha$-pinene itself).

Figure $3 \mathrm{a}$ also shows a wedge of 2-D space one would expect products to occupy if functionalization were the only significant chemical process leading to $\alpha$-pinene products. The relations for $-\mathrm{OH}$ and $=\mathrm{O}$ functionalization as well as the assumed average (similar to organic acid functionalization) are shown as red dashed lines: this wedge follows the ranges described in Donahue et al. (2011) and shows that the observed (first-generation) VBS product distribution and the properties of specific product molecules all fall within the general region expected based on the functionalization wedge.

It is also of interest to note the location of the OOA factors, as well as macromolecules ("oligomers") that are constructed from monomers in the $\alpha$-pinene SOA distribution shown in Figs. 3 and 4. The first-generation products barely reach into the SV-OOA range, overlapping for the highest ambient $C_{\mathrm{OA}}$ cases where volatile SVOC may contribute to OA. They are far from the LV-OOA range. Dimers would fall in the range shown by the dashed oval labeled 'oligomers'. These dimers constructed of the first-generation $\alpha$-pinene monomers miss the OOA target; however, there is evidence for their formation in laboratory experiments (Kalberer et al., 2004; Tolocka et al., 2004; Heaton et al., 2007, 2009). While these oligomers do move the volatility distribution from the reaction closer to the "target" provided by LV-OOA, because they are non-oxidative reactions they do $n o t$ address the degree of oxidation seen in LV-OOA. The same is true for suppressed evaporation of semi-volatile SOA (Vaden et al., 2011); this could decrease the apparent volatility of the SOA but would not address the shortfall in oxidation. More highly oxidized monomers may be more likely to contribute to atmospheric LV-OOA, as they would start out 
with a sufficiently high $\overline{\mathrm{OS}}_{\mathrm{C}}$. However, we must be cautious if significant condensed-phase oligomerization occurs with variable yields over the course of the $\alpha$-pinene SOA experiments, as this would invalidate the important assumption that the overall product distribution remains constant during an experiment, and thus complicate the interpretation of Fig. 2a.

In summary, carbon mass balances of chamber experiments, AMS $\overline{\mathrm{OS}}_{\mathrm{C}}$ data, dilution experiments, and the properties of known first-generation monomeric products form a self-consistent picture of "simple" SOA formation from $\alpha$ pinene $+\mathrm{O}_{3}$.

\subsection{SOA formation from SVOC and IVOC}

Another important class of precursors is the lower-volatility organic vapors (IVOCs and SVOCs) shown in Fig. 1. In this section we describe the transformation of these materials and how that is related to the "targets" described in Sect. 3.

As soon as $\mathrm{OH}$ radicals are introduced into a system, the condition that the product composition remain constant in time is violated. Data inversion (determination of a product $C^{*}$ distribution from SOA mass yields) is much more difficult because the product distribution is almost guaranteed to evolve continuously during an experiment when $\mathrm{OH}$ is involved. These become aging experiments, with oxidation products themselves subject to further oxidation and thus a continually evolving, multi-generational mix of products. Our ultimate approach to quantifying yields will be to develop a full 2-D-VBS OA aging model and to compare forward model predictions with the chamber data. We shall present this prognostic analysis in a subsequent publication. However, we can use the 2-D space in the diagnostic mode to assess the general characteristics of aging chemistry. To illustrate this we shall now consider two important examples of aging applied to systems traditionally associated with POA - woodsmoke and diesel emissions.

There are significant atmospheric emissions of SVOCs and IVOCs (typically with carbon numbers $>C_{10}$ or so) (Donahue et al., 2009; Robinson et al., 2010), as shown in Fig. 1. Many of these vapors are co-emitted with POA from traditional sources such as motor vehicles or biomass combustion. They can also form from evaporating primary particles as they dilute in the atmosphere (Robinson et al., 2010). In recent work we have shown that vapors from these sources can be a significant SOA source (Robinson et al., 2007; Grieshop et al., 2009b; Presto et al., 2009; Miracolo et al., 2010). These compounds partition to the gas phase as the emissions are diluted in the atmosphere (Lipsky and Robinson, 2006; Shrivastava et al., 2008; Dzepina et al., 2009; Tsimpidi et al., 2010), and photochemical oxidation leads to substantial SOA formation, often doubling or tripling the aerosol mass in experiments (Weitkamp et al., 2007; Grieshop et al., 2009b). There is often much more added SOA mass than traditional, volatile precursors can produce, and based on our analysis of dilution data the concentration of vapors in these experiments with $100<\mathrm{C}^{*}<10^{5} \mu \mathrm{g} \mathrm{m}^{-3}\left(C_{15}-C_{20}\right.$ compounds) is a factor of 3-10 greater than the aerosol mass at the beginning of the experiments.

AMS spectra of OA from photooxidation of wood smoke (Grieshop et al., 2009a) and diesel emissions (Sage et al., 2008) provide constraints on the progressive oxidation of the SOA formed from these emissions. Unlike the wellconstrained $\alpha$-pinene system illustrated in Fig. 3, evaporated primary emissions comprise a complex ensemble of precursor vapors forming condensed-phase products with a broad range of volatilities. We must thus confront both progressive oxidation chemistry and a distribution of precursor volatilities (and other properties) when diagnosing these systems. The 2-D volatility-oxidation space can aid this diagnostic analysis: we know the mean properties of OA throughout this space, and data constrain both coordinates as they evolve in experiments or in the atmosphere. We shall use wood smoke and diesel emissions to illustrate this process.

\subsubsection{Wood smoke}

Wood smoke is a highly variable source (McMeeking et al., 2009), but most cases reported by Grieshop et al. (2009b) saw substantial SOA formation in a few hours of photochemical oxidation. Fig. 5 shows results from one experiment, including an inset showing the evolving oxidation during photochemical oxidation (derived from Q-AMS data based on the fraction of organic signal at $\left.m / z=44, f_{44}\right)$ on the bottom panel and thermodenuder data (mass fraction remaining at $50^{\circ} \mathrm{C}$ and $70^{\circ} \mathrm{C}$ ) on the upper panel. The OA mass increased by a factor of 2.5 during this experiment (Grieshop et al., 2009b).

The fresh BBOA AMS spectrum resembled other BBOA samples (Grieshop et al., 2009a), falling in the BBOA range of the 2-D-VBS shown in Fig. 1. Thermodenuder data showed that approximately half of the fresh BBOA mass evaporated at $50^{\circ} \mathrm{C}$, with little change in $f_{44}$, suggesting that most of the particle-phase BBOA was confined within a narrow range in volatility within roughly an order of magnitude of the critical value of $C^{*}=C_{\mathrm{OA}}$ (Grieshop et al., 2009c). However, at $70^{\circ} \mathrm{C}, 3 / 4$ of the mass evaporated and $f_{44}$ increased sharply, suggesting a tail of more oxidized, less volatile material in the fresh BBOA. We use these data to locate BBOA in Fig. 5. The brown oval marked "BBOA" spans about 1 decade of volatility. This oval is, very roughly, a contour surrounding $\sim 50 \%$ of the BBOA mass.

The inset of Fig. 5 shows that the whole sample $(\mathrm{POA}+\mathrm{SOA})$ became dramatically more oxidized after only a few hours of photochemistry, and heating to $70^{\circ} \mathrm{C}$ was required to evaporate half of the OA mass (with a corresponding sharp rise in $f_{44}$ ). In $2 \mathrm{~h}$ the OA mass doubled from 60 to $120 \mu \mathrm{g} \mathrm{m}^{-3}$, and by the end of the experiment $C_{\mathrm{OA}}$ had nearly tripled (Grieshop et al., 2009b). We conclude that the aged OA was spread over a wider volatility range (at least 2 decades) and that it was much more oxidized. 


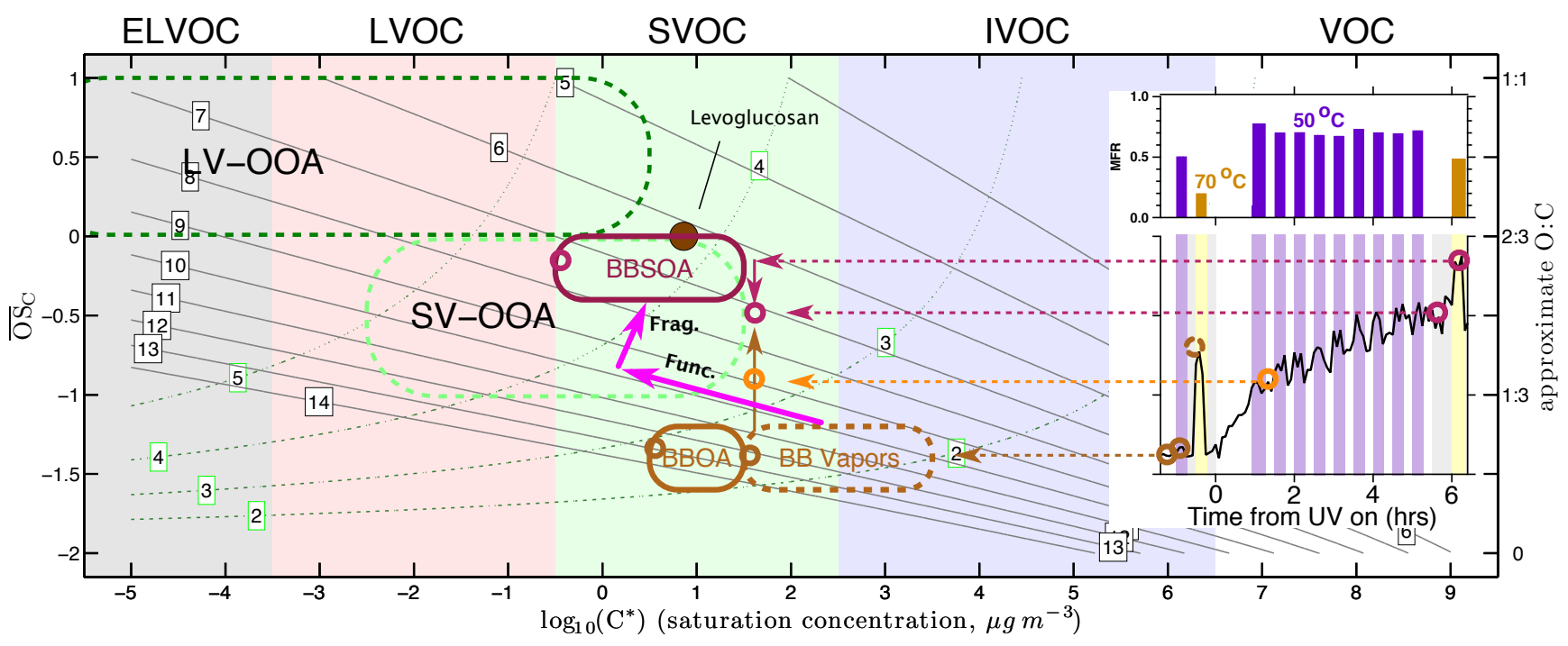

Fig. 5. Evolution of volatility and oxidation for biomass burning aerosol (BBOA) subjected to photochemical oxidation by OH radicals. The inset shows the time evolution in the lower panel (registered to the O:C-axis) while the upper panel shows the mass fraction remaining in a $16 \mathrm{~s}$ thermodenuder operating frequently at $50{ }^{\circ} \mathrm{C}$ (blue stripes) and at the beginning and end of the experiment at $70{ }^{\circ} \mathrm{C}$ (gold stripes) as well. Horizontal dashed lines show the translation of these data to the 2-D-VBS space. The contours suggest a mixture of fresh BBOA with secondary BBSOA (see text). Contours are carbon number (gray) and oxygen number (dashed green) from Donahue et al. (2011).

The inset presents $f_{44}$ (registered to the 2-D-VBS y-axis) for the whole OA sample, which is a mixture of unoxidized BBOA and SOA generated via photochemistry (BBSOA). While we do not know how much of the original BBOA material may have been oxidized, possibly via "semi-volatile pumping" (Miracolo et al., 2010), there was at least 2 times as much SOA as BBOA at the end of the experiment. If the BBOA were unaltered, we would expect it to substantially but not completely evaporate at $50^{\circ} \mathrm{C}$ and almost completely vanish at $70^{\circ} \mathrm{C}$; thus the $70^{\circ} \mathrm{C}$ mass spectrum at the end of the experiment should be mostly SOA. There are two potential solutions describing this time evolution. One is that the SOA became progressively more oxidized over the course of the experiment, while the other is that the SOA was always highly oxidized but that there was progressively more of it, making the mixture of BBOA and SOA continually rise in $\overline{\mathrm{OS}}_{\mathrm{C}}$. Of course, a combination of these solutions is possible.

One way to assess the properties of the SOA is to subtract the POA (BBOA) contribution from the AMS spectrum. Levoglucosan is commonly used as a tracer for BBOA in ambient samples, both through chromatographic analysis (Simoneit et al., 2004) and using the $m / z=60$ fragment (Lee et al., 2010b). A residual spectrum (at room temperature) obtained by subtracting out BBOA based on the levoglucosan marker fragment shows $\mathrm{O}: \mathrm{C} \simeq 0.625\left(\overline{\mathrm{OS}}_{\mathrm{C}} \simeq-0.125\right)$ based on $f_{44}$ (Grieshop et al., 2009a), which is similar to the $\overline{\mathrm{OS}}_{\mathrm{C}}$ at $70^{\circ} \mathrm{C}$ at the end of the experiment. A complication is that levoglucosan is not the only contributor to the unit mass resolution signal at $m / z=60$ (Grieshop et al., 2009a). We show a BBSOA region in Fig. 5 with $\overline{\mathrm{OS}}_{\mathrm{C}} \simeq-0.125$ that is consistent with either solution at the end of the 6-h experiment. Again, this contour surrounds approximately half of the BBSOA material (though the y range of the $50 \%$ contour is difficult to specify. This contour does not slope in $\overline{\mathrm{OS}}_{\mathrm{C}}$ because there is not sufficient information to define that slope. However, the total spectrum at the end of the experiment should be a combination of BBSOA and BBOA with a roughly 2:1 mixing ratio for low thermodenuder temperature but should be more or less pure BBSOA at $70^{\circ} \mathrm{C}$, and that is consistent with the vertical mixing arrows shown.

Levoglucosan is shown in Fig. 5, and its location suggests some hazards. First, levoglucosan is far from the mean properties of BBOA as determined by AMS measurements, and one might want a tracer to be more representative of those properties. However, as we have emphasized, the ovals locating the AMS factors loosely represent a $50 \%$ contour for the total factor mass; individual constituents can lie well outside of those contours, and this is a case in point. A more significant issue is that the $m / z=60$ signal in these experiments decayed more rapidly than simple dilution by SOA could explain (Grieshop et al., 2009a). At least some of that decay could be because levoglucosan is semi volatile, though heterogeneous oxidation can surely have played a role as well (Hennigan et al., 2010). An ideal tracer for a source-specific factor might have an $\overline{\mathrm{OS}}_{\mathrm{C}}$ similar to the mean of the factor but a $C^{*}$ toward the low-volatility end of the source distribution. 


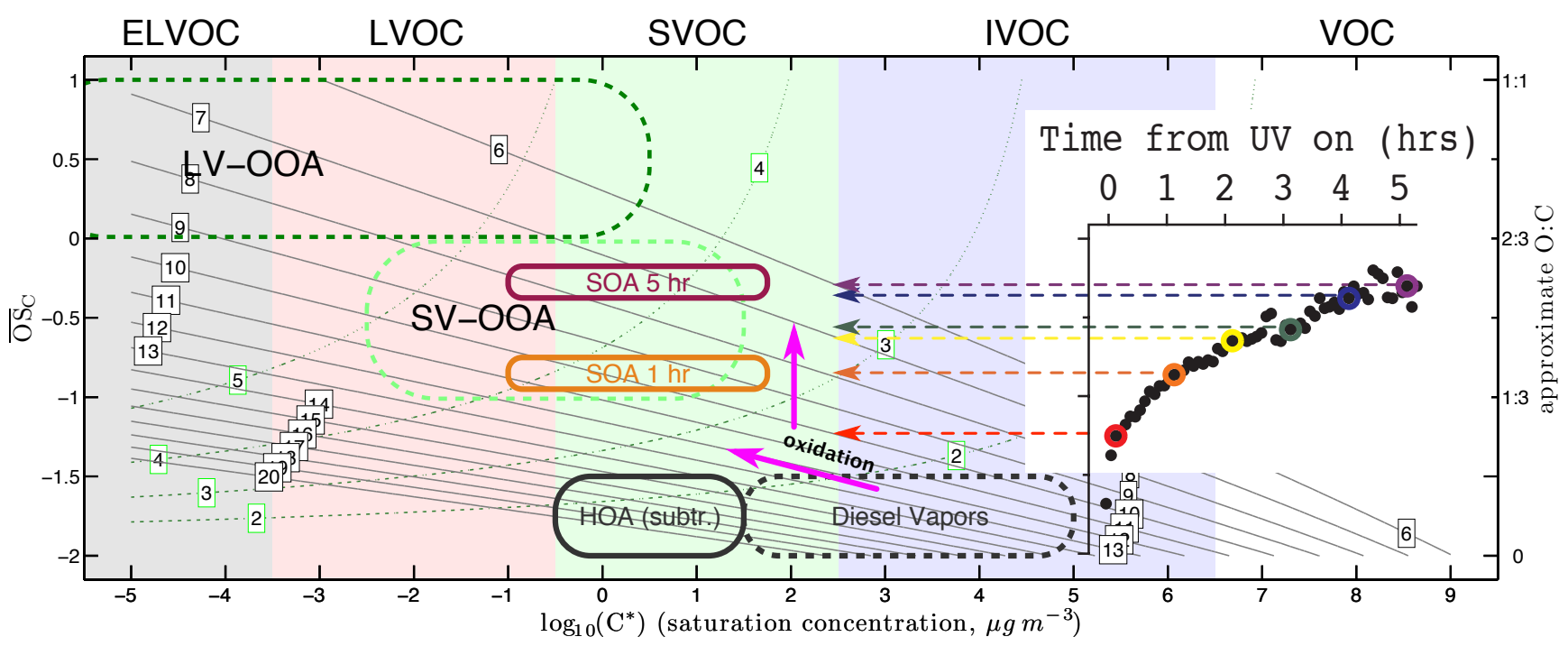

Fig. 6. Progressive oxidation of secondary organic aerosol produced by oxidation of diesel vapors. The inset shows the oxidation state of a residual mass spectrum (HOA removed). $\overline{\mathrm{OS}}_{\mathrm{C}}$ rises steadily through the experiment; the value at each hour is indicated with a colored circle and colored lines mapping to the 2-D-VBS. Contours are carbon number (gray) and oxygen number (dashed green) as in Fig. 5.

The source of the BBSOA is the next question. Modeling by Grieshop et al. (2009a) indicates that it can not be explained based on the measured decay of volatile SOA precursors (e.g. mono-terpenes, single-ring aromatics). Based on dilution data, we know that a large pool of vapors lie just to the right of the BBOA oval in Fig. 5 (Lipsky and Robinson, 2006; Shrivastava et al., 2006). Those vapors are located roughly by the dashed brown contour in the figure. With the onset of photochemistry, oxidation products will tend to move along the gray, constant carbon number isopleths as they functionalize, possibly moving toward the upper right as well as they fragment (these steps are indicated with magenta arrows). The BBSOA at the end of the experiment is consistent with compounds near $\mathrm{C}_{7} \mathrm{O}_{4}$, whereas the precursors are likely to have been $\mathrm{C}_{11}-\mathrm{C}_{13}$ with perhaps 2 oxygen atoms. Because traditional, low carbon-number VOC precursors cannot explain its production, and because we know the higher carbon-number precursors are present, we conclude that fragmentation (at least one $\mathrm{C}$ - $\mathrm{C}$ bond cleavage) has played a role in BBSOA formation during at least two generations of oxidation chemistry (the dashed-green contours indicating oxygen number should be proportional to generation number, with 1-2 oxygen atoms being added per generation).

In this experiment we can not yet tell whether the aggregate $\overline{\mathrm{OS}}_{\mathrm{C}}$ shown in Fig. 5 rises continuously because the $\overline{\mathrm{OS}}_{\mathrm{C}}$ for the BBSOA components is rising via aging or whether progressively more BBSOA with more or less constant composition is simply being mixed into the bulk spectrum. To answer that question we turn to a dataset where the SOA component is separated from a POA factor during the data analysis.

\subsubsection{Diesel emissions}

We have analyzed an evolving residual (SOA) spectrum during diesel-exhaust aging experiments (Sage et al., 2008). Oxidation of diesel emissions under pseudo-ambient conditions also forms highly oxidized OA in a matter of hours, as shown in Fig. 6. The inset in this figure shows $\overline{\mathrm{OS}}_{\mathrm{C}}$ (estimated from $f_{44}$ ) for the residual aerosol (i.e., after subtracting off a static POA component closely resembling published HOA spectra). The data are shown as a function of time in the inset and in the 2-D space with colored circles and arrows in Fig. 6. We observed rapid growth in $\overline{\mathrm{OS}}_{\mathrm{C}}$ of the SOA in these experiments (Sage et al., 2008). $\overline{\mathrm{OS}}_{\mathrm{C}}$ rose rapidly at first and then more slowly over the final several hours, as shown in Fig. 6. Thermodenuder data from separate diesel oxidation experiments are similar to those shown for woodsmoke in Fig. 5, with a quick rise in the mass fraction remaining with the onset of oxidation followed by a more or less stable (but still relatively volatile) thermogram for the duration of the experiment (Miracolo et al., 2010).

Viewed in the 2-D space, the SOA loci from this experiment rise vertically as oxidation progresses, as indicated by the ovals labeled "SOA $1 \mathrm{~h}$ " and "SOA 5 h" in Fig. 6. Initially the SOA is barely distinguishable from HOA, but after only $1 \mathrm{~h}$ it is well within the range of the SV-OOA factor. By the end of the 5-h experiment (much like the wood-smoke in Fig. 5), it is near the high end of $\overline{\mathrm{OS}}_{\mathrm{C}}$ for SV-OOA. Traditional SOA precursors such as toluene can explain only a small fraction of the SOA; Weitkamp et al. (2007) even spiked some experiments with large aliquots of toluene and observed little additional SOA formation. The SOA was thus 
formed by oxidation of vapors from evaporated POA, indicated in the figure with a dashed black contour. Experiments on n-alkane analogues for these vapors (Presto et al., 2009, 2010) as well as evaporated mixtures of diesel fuel and motor oil (Miracolo et al., 2010) confirm that these HOA vapors are a potent SOA source.

There are two potential explanations for the progressive rise in $\overline{\mathrm{OS}}_{\mathrm{C}}$ shown in Fig. 6. One (which we consider less likely) is that SOA formed from oxidation of a succession of precursors whose oxidation roughly followed the gray carbon isopleths. Lower volatility $\left(\sim C_{20}\right)$ vapors would form SOA immediately, while more volatile vapors would require multiple generations of oxidation to generate SOA (Presto et al., 2010). This would build up a mixture of progressively more oxidized SOA constituents. For example, $C_{9}-C_{11}$ precursors could be the source of SOA observed at $1 \mathrm{~h}$ (shown with an orange contour in Fig. 6), while smaller carbonnumber precursors could be the major source for SOA observed at $5 \mathrm{~h}$ (purple contour). In this model, the SOA would be formed with minimal fragmentation.

The other explanation (which we consider more likely) is that the SOA itself aged over the course of the experiment, with progressive fragmentation of semi-volatile compounds driving the average carbon number from roughly 12 early in the experiment to roughly 7 after $5 \mathrm{~h}$. For the first mechanism to dominate, the incremental SOA being formed in the final hours would have to be extremely oxidized in order to average out the less oxidized material formed earlier (when the aerosol mass increases were also steeper). Furthermore, the $C_{7}$ carbon number consistent with the SOA at the end of the experiment is inconsistent with calculations of SOA formation from measured VOC precursors (Weitkamp et al., 2007). Consequently, it is likely that aging and fragmentation of SOA formed early in the experiment (and almost certainly HOA) (Presto et al., 2009; Miracolo et al., 2010) was the major cause for the steadily rising $\overline{\mathrm{OS}}_{\mathrm{C}}$. This aging chemistry is likely dominated by oxidation of the gas-phase fraction of SVOC components (Miracolo et al., 2010).

If the second mechanism dominates over the first mechanism, there must be a significant amount of fragmentation in the overall process, resulting in highly-oxidized products with $C^{*}$ in the LVOC and SVOC range and thus 7-10 carbon atoms. This fragmentation is consistent with our overall understanding of hydrocarbon oxidation - as substitution around carbon bonds increases, the probability of carbon bond fragmentation increases as well (Lim and Ziemann, 2009; Kroll et al., 2009; Chacon Madrid et al., 2010). For lighter hydrocarbons, this fragmentation leads to very volatile products such as formaldehyde, acetone, and other highly oxidized vapors. However, for very large hydrocarbons the intermediate products will have substituents situated more or less randomly along the carbon backbone. If molecules fragment at a random location along the carbon backbone, the mass distribution of the products will favor larger carbon numbers; the median carbon number will be about $75 \%$ of the parent compound carbon number. Thus, after fragmentation, the modal carbon number of a $C_{20}$ precursor is roughly $C_{15}$, but the distribution is broad.

The data shown in Fig. 6 show conclusively that the oxidation state of SOA in these experiments can rise with time via oxidation chemistry. However, the same data were analyzed using factor analysis tools described by Zhang et al. (2005), revealing fixed factors more or less identical to HOA and the most oxidized SOA (the purple symbol at 5h oxidation). A good solution emerged in which the fraction of the oxidized SOA simply rose with time as the overall aerosol became more oxidized (Sage et al., 2008). This is an essential issue with factor-analysis methods: to the extent that spectra of intermediate states (for example the orange symbol in Fig. 6) are linear combinations of two terminal spectra, there is no way to tell the difference between a 50-50 mixture of those terminal constituents and aerosol that is of uniform, intermediate composition. Factors can represent either two distinct pools of material with variable mixing ratios or two endpoints in a continuous and evolving distribution.

The average $\overline{\mathrm{OS}}_{\mathrm{C}}$ clearly increases during the 5-6h typical of our experiments. While added oxygen is necessary for increased $\overline{\mathrm{OS}}_{\mathrm{C}}$, the carbon number is decreasing as well (Kroll et al., 2011), as the constituents cross a succession of carbon-number isopleths, moving continuously toward lower carbon numbers. The first reaction step may involve relatively little fragmentation with the addition of 2-3 oxygens to the carbon backbone, while subsequent steps involve both fragmentation and increasing oxygen content.

\subsubsection{General SVOC and IVOC behavior}

We have begun to explore this mechanism systematically using n-alkanes and oxygenated compounds spanning the SVOC and IVOC range. We do observe substantial SOA formation and - when the OA mass is kept very low - sharp increases in $\overline{\mathrm{OS}}_{\mathrm{C}}$ (Presto et al., 2009, 2010). Thermograms are consistent with significant fragmentation in later-generation products (Presto et al., 2009). However, alkanes alone do not generally produce high $\overline{\mathrm{OS}}_{\mathrm{C}}$ products under the same conditions as these diesel experiments, suggesting that other constituents in the diesel emissions may be important contributors.

Sequences at roughly constant $C^{*}$ consisting of progressively more oxygenated compounds show decreased SOA formation with increasing oxygenation, along with gas-phase product molecules consistent with fragmentation (Chacon Madrid et al., 2010; Chacon Madrid and Donahue, 2011). All of these experiments support the general finding that fragmentation processes become more important with increasing substitution associated with increasing oxygenation during OA aging.

Most of this discussion focuses on products in the condensed phase (that we observe with the AMS); for example, the initial products with $\overline{\mathrm{OS}}_{\mathrm{C}} \simeq-1.5$ emerge quickly in the 


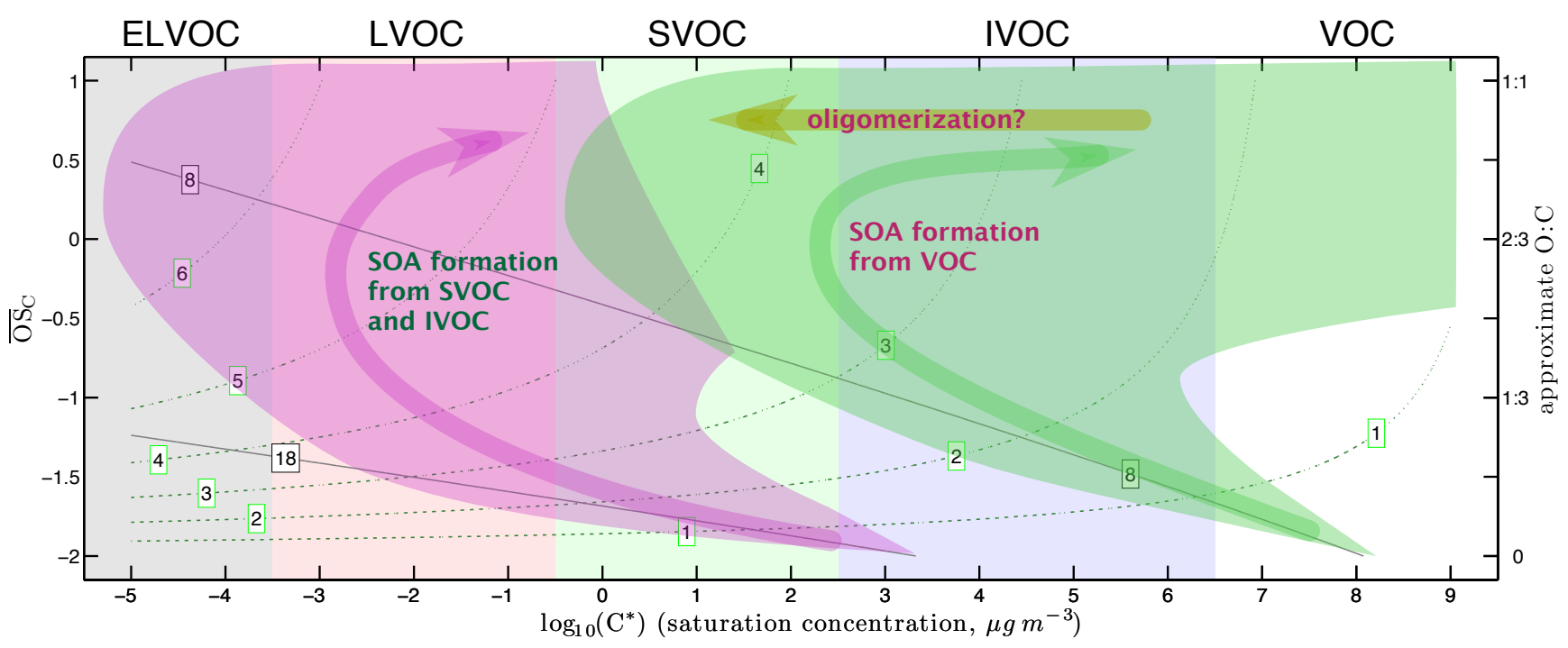

Fig. 7. Two reaction trajectories in 2-D space. Contours are carbon number (gray) and oxygen number (dashed green) as in Fig. 5. SOA formed from VOCs (shown at $\mathrm{C}_{8}$ ) moves rapidly upward in $\overline{\mathrm{OS}}_{\mathrm{C}}$ but reaches a minimum in $C^{*}$ only barely sufficient to form any SOA in the atmosphere. SOA formed from SVOCs and IVOCs (shown at $\mathrm{C}_{18}$ ) moves more slowly upward in $\overline{\mathrm{OS}}_{\mathrm{C}}$ but reaches very low $C^{*}$ values. Both trajectories ultimately result in complete fragmentation (in the limit where the chemistry is allowed to continue to completion), and both consist of a cloud of individual reaction pathways initially centered on the mean carbon contour for the parent carbon number. A potential oligomerization trajectory is shown as well.

diesel experiment, but this does not constrain the overall oxidation state of the reaction products, as it is likely that only the most oxidized products appear in the condensed phase.

\section{Conclusions}

We have described the use of a two-dimensional volatilityoxidation space as a tool for diagnosing organic-aerosol behavior. The coordinates are organic volatility $\left(C^{*}\right)$ and the average carbon oxidation state $\left(\overline{\mathrm{OS}}_{\mathrm{C}}\right)$. Because we know the average composition of compounds in this space (Donahue et al., 2011), we plot observational data and gain insight into the chemistry driving OA evolution. An important feature of the diagnostic mode is that we do not need to know the molecular composition in the space to infer broad patterns in OA behavior. Data for traditional SOA formation (the $\alpha$-pinene + ozone system) are self-consistent when considered in this space, with the bulk volatility and oxidation state matching values of important known products. More complex systems such as diesel and wood-smoke vapors are characterized by progressively increasing mean carbon oxidation states, as expected based on thermodynamic constraints. However, the more complex systems in particular also show evidence for extensive fragmentation of the carbon backbones during SOA formation (Presto et al., 2009; Kroll et al., 2009).

The 2-D space allows us to constrain average organic properties much more tightly than our earlier 1-D-VBS (Donahue et al., 2006). The oxidation dimension gives us better predictions of the total organic mass (OM/OC) as well as OA properties, such as solubility, that are important to climate and perhaps health effects. We are thus developing a prognostic 2-D-VBS to efficiently model organic-aerosol chemical aging (Murphy et al., 2011). Full development of a 2-DVBS model will require parameterization of oxidation kinetics well beyond the first one or two generations of oxidation chemistry, where organic behavior is relatively well understood (Atkinson, 1997; Jordan et al., 2008), to later generations where the chemistry is uncertain.

While the discussion in this work has focused on gasphase chemistry, thermodynamic frameworks are agnostic about which phase chemical evolution occurs in. Thermodynamics are path independent. Thus, heterogeneous, condensed-phase, and aqueous-phase processes can be accommodated. Furthermore, as viscosity, molar weight, volatility, and molecular polarity are inter-related, we plan to treat condensed-phase dynamics in the future as well.

The implications of this work are summarized in Fig. 7 , which shows hypothetical reaction trajectories for two model systems. This figure selects only two carbon isopleths but shows each oxygen isopleth for the mean group contribution method we will use for our prognostic 2-D-VBS; the oxygen isopleths represent a sort of generation count, at least before the onset of fragmentation in the reaction mechanism. Our challenge is to measure and model both the mean trajectories (shown with arrows) but more importantly the full 
breadth of these trajectories as well as the kinetics - the rate at which organics progress through the trajectories. Both trajectories show increasing fragmentation as $\overline{\mathrm{OS}}_{\mathrm{C}}$ rises, consistent with Kroll et al. (2011), and both trajectories (especially the $C_{18}$ ) will involve thousands of individual compounds as the mechanism pushes into later generations (Donahue et al., 2005; Aumont et al., 2005). Especially in the non-traditional trajectory, heterogeneous chemistry will clearly be of major importance, and in both cases accretion reactions, with the possibility of adding to the product carbon numbers, add yet another layer of complexity to the challenge. However, whatever mechanisms are ultimately responsible for delivering carbon to the upper left region of Fig. 7 in the atmosphere (forming LV-OOA), one conclusion that is unavoidable is that extensive oxidation chemistry must be involved.

\section{Supplementary material related to this article is available online at: \\ http://www.atmos-chem-phys.net/12/615/2012/ acp-12-615-2012-supplement.pdf.}

Acknowledgements. This work was funded by the National Science Foundation, the EPA STAR program, the Electric Power Research Institute (EPRI), and the European Research Council (project ATMOPACS).

Edited by: M. C. Facchini

\section{References}

Aiken, A. C., DeCarlo, P. F., Kroll, J. H., Worsnop, D. R., Huffman, J. A., Docherty, K., Ulbrich, I. M., Mohr, C., Kimmel, J. R., Sueper, D., Zhang, Q., Sun, Y., Trimborn, A., Northway, M., Ziemann, P. J., Canagaratna, M. R., Alfarra, R., Prevot, A. S., Dommen, J., Duplissy, J., Metzger, A., Baltensperger, U., and Jimenez, J. L.: O/C and OM/OC Ratios of Primary, Secondary, and Ambient Organic Aerosols with High Resolution Time-ofFlight Aerosol Mass Spectrometry, Env. Sci. Technol., 42, 44784485, 2008.

An, W. J., Pathak, R. K., Lee, B.-H., and Pandis, S. N.: Aerosol volatility measurement using an improved thermodenuder: Application to secondary organic aerosol, J. Aerosol. Sci., 38, 305314, doi:10.1016/j.jaerosci.2006.12.002, 2007.

Atkinson, R.: Gas phase tropospheric chemistry of organic compounds, J. Phys. Chem. Ref. Data, 26, 215-290, 1997.

Aumont, B., Szopa, S., and Madronich, S.: Modelling the evolution of organic carbon during its gas-phase tropospheric oxidation: development of an explicit model based on a self generating approach, Atmos. Chem. Phys., 5, 2497-2517, doi:10.5194/acp-52497-2005, 2005.

Canagaratna, M. R., Jayne, J. T., Jimenez, J. L., Allan, J. D., Alfarra, M. R., Zhang, Q., Onasch, T. B., Drewnick, F., Coe, H., Middlebrook, A., Delia, A., Williams, L. R., Trimborn, A. M., Northway, M. J., DeCarlo, P. F., Kolb, C. E., Davidovits, P., and Worsnop, D. R.: Chemical and microphysical characterization of ambient aerosols with the Aerosol Mass Spectrometer, Mass Spectrom. Rev., 26, 185-222, 2007.

Cappa, C. D. and Jimenez, J. L.: Quantitative estimates of the volatility of ambient organic aerosol, Atmos. Chem. Phys., 10, 5409-5424, doi:10.5194/acp-10-5409-2010, 2010.

Carlton, A. G., Turpin, B. J., Lim, H.-J., Altieri, K. E., and Seitzinger, S.: Link between isoprene and secondary organic aerosol (SOA): Pyruvic acid oxidation yields low volatility organic acids in clouds, Geophys. Res. Lett., 33, L06822, doi:10.1029/2005GL025374, 2006.

Chacon-Madrid, H. J. and Donahue, N. M.: Fragmentation vs. functionalization: chemical aging and organic aerosol formation, Atmos. Chem. Phys., 11, 10553-10563, doi:10.5194/acp11-10553-2011, 2011.

Chacon Madrid, H. J., Presto, A. A., and Donahue, N. M.: Functionalization vs Fragmentation: n-Aldehyde Oxidation Mechanisms and Secondary Organic Aerosol Formation, Phys. Chem. Chem. Phys., 12, 13975-13982, doi:10.1039/c0cp00200c, 2010.

Chen, Q., Liu, Y., Donahue, N. M., Shilling, J. E., and Martin, S. T.: Particle-Phase Chemistry of Secondary Organic Material: Model and Measurement of O:C and H:C Elemental Ratios Provide Constraints, Environ. Sci. Technol., 45, 4763-4770, doi:10.1021/es104398s, 2011.

Chung, S. H. and Seinfeld, J. H.: Global Distribution and Climate Forcing of Carbonaceous Aerosols, J. Geophys. Res., 107, 4407, doi:doi:10.1029/2001JD001397, 2002.

Cruz, C. N. and Pandis, S. N.: A study of the ability of pure secondary organic aerosol to act as cloud condensation nuclei, Atmos. Environ., 31, 2205-2214, 1997.

Cruz, C. N. and Pandis, S. N.: The effect of organic coatings on the cloud condensation nuclei activation of inorganic atmospheric aerosol, J. Geophys. Res.-Atmos., 103, 13111-13123, 1998.

Donahue, N. M., Hartz, K. E. H., Chuong, B., Presto, A. A., Stanier, C. O., Rosenhorn, T., Robinson, A. L., and Pandis, S. N.: Critical factors determining the variation in SOA yields from terpene ozonolysis: A combined experimental and computational study, Faraday Discuss., 130, 295-309, 2005.

Donahue, N. M., Robinson, A. L., Stanier, C. O., and Pandis, S. N.: Coupled partitioning, dilution, and chemical aging of semivolatile organics, Environ. Sci. Technol., 40, 2635-2643, 2006.

Donahue, N. M., Robinson, A. L., and Pandis, S. N.: Atmospheric Organic Particulate Matter: From Smoke to Secondary Organic Aerosol, Atmos. Environ., 43, 94-106, doi:10.1016/j.atmosenv.2008.09.055, 2009.

Donahue, N. M., Epstein, S. A., Pandis, S. N., and Robinson, A. L.: A two-dimensional volatility basis set: 1. organic-aerosol mixing thermodynamics, Atmos. Chem. Phys., 11, 3303-3318, doi:10.5194/acp-11-3303-2011, 2011.

Dzepina, K., Volkamer, R. M., Madronich, S., Tulet, P., Ulbrich, I. M., Zhang, Q., Cappa, C. D., Ziemann, P. J., and Jimenez, J. L.: Evaluation of recently-proposed secondary organic aerosol models for a case study in Mexico City, Atmos. Chem. Phys., 9, 5681-5709, doi:10.5194/acp-9-5681-2009, 2009.

Epstein, S. A., Riipinen, I., and Donahue, N. M.: A Semi-Empirical Correlation between Enthalpy of Vaporization and Saturation Concentration for Organic Aerosol, Environ. Sci. Technol., 44, 743-748, doi:10.1021/es902497z, 2010.

Ervens, B. and Volkamer, R.: Glyoxal processing by aerosol 
multiphase chemistry: towards a kinetic modeling framework of secondary organic aerosol formation in aqueous particles, Atmos. Chem. Phys., 10, 8219-8244, doi:10.5194/acp-10-82192010, 2010.

Fraser, M. P., Cass, G. R., Simoneit, B. R. T., and Rasmussen, R. A.: Air quality model evaluation data for organics. 4. $\mathrm{C}_{2}-\mathrm{C}_{36}$ nonaromatic hydrocarbons, Environ. Sci. Technol., 31, 2356-2367, 1997.

Gaydos, T. M., Pinder, R., Koo, B., Fahey, K. M., Yarwood, G., and Pandis, S. N.: Development and application of a three-dimensional aerosol chemical transport model, PMCAMx, Atmos. Environ., 41, 2594-2611, doi:10.1016/j.atmosenv.2006.11.034, 2007.

George, I. J., Slowik, J., and Abbatt, J. P. D.: Chemical aging of ambient organic aerosol from heterogeneous reaction with hydroxyl radicals, Geophysical Research Letters, 35, L13811, doi:10.1029/2008GL033884, 2008.

Goldstein, A. H. and Galbally, I. E.: Known and Unexplored Organic Constituents in the Earth's Atmosphere, Environ. Sci. Technol., 41, 1515-1521, 2007.

Grieshop, A. P., Donahue, N. M., and Robinson, A. L.: Is the Gas-Particle Partitioning in $\alpha$-Pinene Secondary Organic Aerosol Reversible?, Geophys. Res. Lett., 34, L14810, doi:10.1029/2007GL029987, 2007.

Grieshop, A. P., Donahue, N. M., and Robinson, A. L.: Laboratory investigation of photochemical oxidation of organic aerosol from wood fires 2: analysis of aerosol mass spectrometer data, Atmos. Chem. Phys., 9, 2227-2240, doi:10.5194/acp-9-2227-2009, 2009.

Grieshop, A. P., Donahue, N. M., and Robinson, A. L.: Laboratory investigation of photochemical oxidation of organic aerosol from wood fires 2: analysis of aerosol mass spectrometer data, Atmos. Chem. Phys., 9, 2227-2240, doi:10.5194/acp-9-2227-2009, 2009.

Grieshop, A. P., Miracolo, M. A., Donahue, N. M., and Robinson, A. L.: Constraining the Volatility Distribution and Gas-Particle Partitioning of Combustion Aerosols Using Isothermal Dilution and Thermodenuder Measurements, Environ. Sci. Technol., 43, 4750-4756, doi:10.1021/es8032378, 2009c.

Griffin, R., Cocker, D., Flagan, R., and Seinfeld, J.: Organic aerosol formation from the oxidation of biogenic hydrocarbons, J. Geophys. Res., 104, 3555, doi:10.1029/1998JD100049, 1999.

Hallquist, M., Wenger, J. C., Baltensperger, U., Rudich, Y., Simpson, D., Claeys, M., Dommen, J., Donahue, N. M., George, C., Goldstein, A. H., Hamilton, J. F., Herrmann, H., Hoffmann, T., Iinuma, Y., Jang, M., Jenkin, M. E., Jimenez, J. L., Kiendler-Scharr, A., Maenhaut, W., McFiggans, G., Mentel, Th. F., Monod, A., Prévôt, A. S. H., Seinfeld, J. H., Surratt, J. D., Szmigielski, R., and Wildt, J.: The formation, properties and impact of secondary organic aerosol: current and emerging issues, Atmos. Chem. Phys., 9, 5155-5236, doi:10.5194/acp-95155-2009, 2009.

Heald, C. L., Kroll, J. H., Jimenez, J. L., Docherty, K. S., DeCarlo, P. F., Aiken, A. C., Chen, Q., Martin, S. T., Farmer, D. K., and Artaxo, P.: A simplified description of the evolution of organic aerosol composition in the atmosphere, Geophys. Res. Lett., 37, GL042 737, doi:10.1029/2010GL042737, 2010.

Heaton, K. J., Dreyfus, M. A., Wang, S., and Johnston, M. V.: Oligomers in the early stage of biogenic secondary organic aerosol formation and growth, Environ. Sci. Technol., 41, 61296136, doi:10.1021/es070314n, 2007.

Heaton, K. J., Sleighter, R. L., Hatcher, P. G., Hall, W. A., and Johnston, M. V.: Composition Domains in Monoterpene Secondary Organic Aerosol, Environ. Sci. Technol., 43, 7797-7802, doi:10.1021/es901214p, 2009.

Hennigan, C. J., Sullivan, A. P., Jeffrey L. Collett, J., and Robinson, A. L.: Levoglucosan Stability in Biomass Burning Particles Exposed to Hydroxyl Radicals, Geophys. Res. Lett., 37, L09 806, doi:10.1029/2010GL043088, 2010.

Hildebrandt, L., Donahue, N. M., and Pandis, S. N.: High formation of secondary organic aerosol from the photo-oxidation of toluene, Atmos. Chem. Phys., 9, 2973-2986, doi:10.5194/acp-92973-2009, 2009.

Hildebrandt, L., Kostenidou, E., Lee, B. H., Mihalopoulos, N., Worsnop, D. R., Donahue, N. M., and Pandis, S. N.: Formation of Low-Volatility Oxygenated Organic Aerosol in the Atmosphere: Insights from the Finokalia Aerosol Measurement Experiments - 2008/2009, Geophys. Res. Lett., 37, L23801, doi:10.1029/2010GL045193, http://www.agu.org/pubs/crossref/ 2010/2010GL045193.shtml, 2010.

Holzinger, R., Williams, J., Herrmann, F., Lelieveld, J., Donahue, N. M., and Röckmann, T.: Aerosol analysis using a ThermalDesorption Proton-Transfer-Reaction Mass Spectrometer (TDPTR-MS): a new approach to study processing of organic aerosols, Atmos. Chem. Phys., 10, 2257-2267, doi:10.5194/acp10-2257-2010, 2010.

Huff Hartz, K. E., Tischuk, J. E., Chan, M. N., Chan, C. K., Donahue, N. M., and Pandis, S. N.: Cloud Condensation Nuclei Activation of Limited Solubility Organic Aerosol, Atmos. Environ., 40, 605-617, doi:10.1016/j.atmosenv.2005.09.076, http: //dx.doi.org/10.1016/j.atmosenv.2005.09.076, 2006.

Huffman, J. A., Docherty, K. S., Aiken, A. C., Cubison, M. J., U1brich, I. M., DeCarlo, P. F., Sueper, D., Jayne, J. T., Worsnop, D. R., Ziemann, P. J., and Jimenez, J. L.: Chemically-resolved aerosol volatility measurements from two megacity field studies, Atmos. Chem. Phys., 9, 7161-7182, doi:10.5194/acp-9-71612009, 2009.

Isaacman, G., Worton, D. R., Kreisberg, N. M., Hennigan, C. J., Teng, A. P., Hering, S. A., Robinson, A. L., Donahue, N. M., and Goldstein, A. H.: Understanding evolution of product composition and volatility distribution through in-situ GCxGC analysis: a case study of longifolene ozonolysis, Atmos. Chem. Phys., 11, 5335-5346, doi:10.5194/acp-11-5335-2011, 2011.

Jang, M. and Kamens, R. M.: Newly characterized products and composition of secondary aerosols from the reaction of alphapinene with ozone, Atmos. Environ., 33, 459-474, 1999.

Jaoui, M. and Kamens, R. M.: Mass balance of gaseous and particulate products analysis from $\alpha$-pinene/ $\mathrm{NO}_{\mathrm{x}} /$ air in the presence of natural sunlight, J. Geophys. Res. A, 106, 12541-12558, 2001.

Jimenez, J. L., Canagaratna, M. R., Donahue, N. M., Prévôt, A. S. H., Zhang, Q., Kroll, J. H., DeCarlo, P. F., Allan, J., Coe, H., Ng, N. L., Aiken, A. C., Docherty, K. D., Ulbrich, I. M., Grieshop, A. P., Robinson, A. L., Duplissy, J., Smith, J. D., Wilson, K. R., Lanz, V. A., Hueglin, C., Sun, Y. L., Laaksonen, A., Raatikainen, T., Rautiainen, J., Vaattovaara, P., Ehn, M., Kulmala, M., Tomlinson, J. M., Collins, D. R., Cubison, M. J., Dunlea, E. J., Huffman, J. A., Onasch, T. B., Alfarra, M. R., Williams, P. I., Bower, K., Kondo, Y., Schneider, J., Drewnick, 
F., Borrmann, S., Weimer, S., Demerjian, K., Salcedo, D., Cottrell, L., Griffin, R., Takami, A., Miyoshi, T., Hatakeyama, S., Shimono, A., Sun, J. Y., Zhang, Y. M., Dzepina, K., Kimmel, J. R., Sueper, D., Jayne, J. T., Herndon, S. C., Trimborn, A. M., Williams, L. R., Wood, E. C., Kolb, C. E., Baltensperger, U., and Worsnop, D. R.: Evolution of Organic Aerosols in the Atmosphere: A New Framework Connecting Measurements to Models, Science, 326, 1525-1529, 2009.

Jordan, C. E., Ziemann, P. J., Griffin, R. J., Lim, Y. B., Atkinson, R., and Arey, J.: Modeling SOA formation from $\mathrm{OH}$ reactions with C-8-C-17 n-alkanes, Atmos. Environ., 42, 8015-8026, 2008.

Kalberer, M., Paulsen, D., Sax, M., Steinbacher, M., Dommen, J., Prevot, A. S. H., Fisseha, R., Weingartner, E., Frankevic, V., Zenobi, R., and Baltensperger, U.: Identification of Polymers as Major Components of Atmospheric Organic Aerosols, Science, 303, 1656-1662, 2004.

Kanakidou, M., Seinfeld, J. H., Pandis, S. N., Barnes, I., Dentener, F. J., Facchini, M. C., Van Dingenen, R., Ervens, B., Nenes, A., Nielsen, C. J., Swietlicki, E., Putaud, J. P., Balkanski, Y., Fuzzi, S., Horth, J., Moortgat, G. K., Winterhalter, R., Myhre, C. E. L., Tsigaridis, K., Vignati, E., Stephanou, E. G., and Wilson, J.: Organic aerosol and global climate modelling: a review, Atmos. Chem. Phys., 5, 1053-1123, doi:10.5194/acp-5-1053-2005, 2005.

Kroll, J. H. and Seinfeld, J. H.: Chemistry of secondary organic aerosol: Formation and evolution of low-volatility organics in the atmosphere, Atmos. Environ., 42, 3593-3624, doi:10.1016/j.atmosenv.2008.01.003, 2008.

Kroll, J. H., Smith, J. D., Che, D. L., Kessler, S. H., Worsnop, D. R., and Wilson, K. R.: Measurement of fragmentation and functionalization pathways in the heterogeneous oxidation of oxidized organic aerosol, Phys. Chem. Chem. Phys., 11, 8005-8014, doi: DOI10.1039/b905289e, 2009.

Kroll, J. H., Donahue, N. M., Jimenez, J. L., Kessler, S., Canagaratna, M. R., Wilson, K., Alteri, K. E., Mazzoleni, L. R., Wozniak, A. S., Bluhm, H., Mysak, E. R., Smith, J. D., Kolb, C. E., and Worsnop, D. R.: Carbon oxidation state as a metric for describing the chemistry of atmospheric organic aerosol, Nature Chemistry, 3, 133-139, doi:10.1038/nchem.948, 2011.

Lanz, V. A., Alfarra, M. R., Baltensperger, U., Buchmann, B., Hueglin, C., and Prévôt, A. S. H.: Source apportionment of submicron organic aerosols at an urban site by factor analytical modelling of aerosol mass spectra, Atmos. Chem. Phys., 7, 1503-1522, doi:10.5194/acp-7-1503-2007, 2007.

Lee, B. H., Kostenidou, E., Hildebrandt, L., Riipinen, I., Engelhart, G. J., Mohr, C., DeCarlo, P. F., Mihalopoulos, N., Prevot, A. S. H., Baltensperger, U., and Pandis, S. N.: Measurement of the ambient organic aerosol volatility distribution: application during the Finokalia Aerosol Measurement Experiment (FAME2008), Atmos. Chem. Phys., 10, 12149-12160, doi:10.5194/acp10-12149-2010, 2010.

Lee, T., Sullivan, A. P., Mack, L., Jimenez, J. L., Kreidenweis, S. M., Onasch, T. B., Worsnop, D. R., W., M., Wold, C. E., Hao, W. M., and Collett, J. L.: Chemical Smoke Marker Emissions During Flaming and Smoldering Phases of Laboratory Open Burning of Wildland Fuels, Aerosol Sci. Tech., 44, i-v, $2010 \mathrm{~b}$.

Lee, B. H., Pierce, J. R., Engelhart, G. J., and Pandis, S. N.: Volatility of secondary organic aerosol from the ozonolysis of monoterpenes, Atmos. Environ., 45, 2443-2452, doi:10.1016/j.atmosenv.2011.02.004, 2011.

Lim, Y. B. and Ziemann, P. J.: Effects of Molecular Structure on Aerosol Yields from $\mathrm{OH}$ Radical-Initiated Reactions of Linear, Branched, and Cyclic Alkanes in the Presence of $\mathrm{NO}_{\mathrm{x}}$, Environ. Sci. Technol., 43, 2328-2334, 2009.

Lipsky, E. M. and Robinson, A. L.: Effects of dilution on fine particle mass and partitioning of semivolatile organics in diesel exhaust and wood smoke, Environ. Sci. Technol., 40, 155-162, 2006.

Marcolli, C., Luo, B. P., Peter, Th., and Wienhold, F. G.: Internal mixing of the organic aerosol by gas phase diffusion of semivolatile organic compounds, Atmos. Chem. Phys., 4, 25932599, doi:10.5194/acp-4-2593-2004, 2004.

McMeeking, G. R., Kreidenweis, S. M., Baker, S., Carrico, C. M., Chow, J. C., Collett, Jr., J. L., Hao, W. M., Holden, A. S., Kirchstetter, T. W., Malm, W. C., Moosmueller, H., Sullivan, A. P., and Wold, C. E.: Emissions of trace gases and aerosols during the open combustion of biomass in the laboratory, J. Geophys. Res.-Atmos., 114, D011 836, doi:10.1029/2009JD011836, 2009.

Miracolo, M. A., Presto, A. A., Lambe, A. T., Hennigan, C. J., Donahue, N. M., Kroll, J. H., Worsnop, D. R., and Robinson, A. L.: Secondary Organic Aerosol Formation from Motor Vehicle Emissions Surrogates, Environ. Sci. Technol., 44, 16381643, doi:10.1021/es902635c, 2010.

Moise, T. and Rudich, Y.: Uptake of $\mathrm{Cl}$ and $\mathrm{Br}$ by organic surfaces - a perspective on organic aerosols processing by tropospheric oxidants, Geophys. Res. Lett., 28, 4083-4086, 2001.

Molina, M. J., Ivanov, A. V., Trakhtenberg, S., and Molina, L. T.: Atmospheric Evolution of Organic Aerosol, Geophys. Res. Lett., 31, L22 104, doi:10.1029/2004GL020910, 2004.

Murphy, B. N., Donahue, N. M., Fountoukis, C., and Pandis, S. N.: Simulating the oxygen content of ambient organic aerosol with the 2-D volatility basis set, Atmos. Chem. Phys., 11, 7859-7873, doi:10.5194/acp-11-7859-2011, 2011.

Ng, N. L., Canagaratna, M. R., Zhang, Q., Jimenez, J. L., Tian, J., Ulbrich, I. M., Kroll, J. H., Docherty, K. S., Chhabra, P. S., Bahreini, R., Murphy, S. M., Seinfeld, J. H., Hildebrandt, L., Donahue, N. M., DeCarlo, P. F., Lanz, V. A., Prvt, A. S. H., Dinar, E., Rudich, Y., and Worsnop, D. R.: Organic aerosol components observed in Northern Hemispheric datasets from Aerosol Mass Spectrometry, Atmos. Chem. Phys., 10, 46254641, doi:10.5194/acp-10-4625-2010, 2010.

Odum, J. R., Hoffmann, T., Bowman, F. A., Collins, D., Flagan, R. C., and Seinfeld, J. H.: Gas/particle partitioning and secondary organic aerosol yields, Environ. Sci. Technol., 30, 25802585, doi:10.1021/es950943+, 1996.

Pandis, S. N., Harley, R. A., Cass, G. R., and Seinfeld, J. H.: Secondary organic aerosol formation and transport, Atmos. Environ. A-Gen., 26, 2269-2282, 1992.

Pankow, J. F.: An absorption model of gas/particle partitioning of organic compounds in the atmosphere, Atmos. Environ., 28, 189-193, doi:10.1016/1352-2310(94)90094-9, 1994.

Pankow, J. F. and Asher, W. E.: SIMPOL.1: a simple group contribution method for predicting vapor pressures and enthalpies of vaporization of multifunctional organic compounds, Atmos. Chem. Phys., 8, 2773-2796, doi:10.5194/acp-8-27732008, 2008.

Pankow, J. F. and Barsanti, K. C.: The carbon numberpolarity grid: A means to manage the complexity of the 
mix of organic compounds when modeling atmospheric organic particulate matter, Atmos. Environ., 43, 2829-2835, doi:10.1016/j.atmosenv.2008.12.050, 2009.

Pankow, J., Seinfeld, J., Asher, W., and Erdakos, G.: Modeling the formation of secondary organic aerosol. 1. Application of theoretical principles to measurements obtained in the $\alpha$-pinene/, $\beta$ pinene/, sabinene/, $\Delta^{3}$-carene/, and cyclohexene/ozone systems, Environ. Sci. Technol., 35, 1164-1172, doi:10.1021/es001321d, 2001.

Pathak, R. K., Presto, A. A., Lane, T. E., Stanier, C. O., Donahue, N. M., and Pandis, S. N.: Ozonolysis of a-pinene: parameterization of secondary organic aerosol mass fraction, Atmos. Chem. Phys., 7, 3811-3821, doi:10.5194/acp-7-3811-2007, 2007.

Presto, A. A. and Donahue, N. M.: Investigation of alpha-pinene plus ozone secondary organic aerosol formation at low total aerosol mass, Environ. Sci. Technol., 40, 3536-3543, 2006.

Presto, A. A., Miracolo, M. A., Donahue, N. M., Robinson, A. L., Kroll, J. H., and Worsnop, D. R.: Intermediate-Volatility Organic Compounds: A Potential Source of Ambient Oxidized Organic Aerosol, Environ. Sci. Technol., 43, 4744-4749, doi:10.1021/es803219q, 2009.

Presto, A. A., Miracolo, M. A., Donahue, N. M., and Robinson, A. L.: Secondary Organic Aerosol Formation from High- $\mathrm{NO}_{\mathrm{x}}$ Photo-Oxidation of Low Volatility Precursors: $n$-Alkanes, Environ. Sci. Technol., 44, 2029-2034, doi:10.1021/es903712r, 2010.

Riipinen, I., Pierce, J. R., Donahue, N. M., and Pandis, S. N.: Equilibration time scales of organic aerosol inside thermodenuders: Evaporation kinetics versus thermodynamics, Atmos. Environ., 44, 597-607, doi:10.1016/j.atmosenv.2009.11.022, 2010.

Robinson, A. L., Donahue, N. M., and Rogge, W. F.: Photochemical oxidation and changes in molecular composition of organic aerosol in the regional context, J. Geophys. Res.-Atmos., 111, D03302, doi:10.1029/2005JD006265, 2006.

Robinson, A. L., Donahue, N. M., Shrivastava, M. K., Weitkamp, E. A., Sage, A. M., Grieshop, A. P., Lane, T. E., Pierce, J. R., and Pandis, S. N.: Rethinking organic aerosols: Semivolatile emissions and photochemical aging, Science, 315, 1259-1262, 2007.

Robinson, A. L., Grieshop, A. P., Donahue, N. M., and Hunt, S. W.: Updating our conceptual model for fine particle mass emissions from combustion systems, J. Am. Waste Manage. Assoc., 60, 1204-1222, doi:10.3155/1047-3289.60.10.1204, 2010.

Rudich, Y., Donahue, N. M., and Mentel, T. F.: Aging of organic aerosol: bridging the gap between laboratory and field studies, Ann. Rev. Phys. Chem., 58, 321-352, doi:10.1146/annurev.physchem.58.032806.104432, 2007.

Saathoff, H., Naumann, K.-H., Möhler, O., Jonsson, . M., Hallquist, M., Kiendler-Scharr, A., Mentel, Th. F., Tillmann, R., and Schurath, U.: Temperature dependence of yields of secondary organic aerosols from the ozonolysis of a-pinene and limonene, Atmos. Chem. Phys., 9, 1551-1577, doi:10.5194/acp-9-1551-2009, 2009.

Sage, A. M., Weitkamp, E. A., Robinson, A. L., and Donahue, N. M.: Evolving mass spectra of the oxidized component of organic aerosol: results from aerosol mass spectrometer analyses of aged diesel emissions, Atmos. Chem. Phys., 8, 1139-1152, doi:10.5194/acp-8-1139-2008, 2008.

Shilling, J. E., Chen, Q., King, S. M., Rosenoern, T., Kroll, J. H., Worsnop, D. R., McKinney, K. A., and Martin, S. T.: Particle mass yield in secondary organic aerosol formed by the dark ozonolysis of $\alpha$-pinene, Atmos. Chem. Phys., 8, 2073-2088, doi:10.5194/acp-8-2073-2008, 2008.

Shilling, J. E., Chen, Q., King, S. M., Rosenoern, T., Kroll, J. H., Worsnop, D. R., DeCarlo, P. F., Aiken, A. C., Sueper, D., Jimenez, J. L., and Martin, S. T.: Loading-dependent elemental composition of a-pinene SOA particles, Atmos. Chem. Phys., 9, 771-782, doi:10.5194/acp-9-771-2009, 2009.

Shrivastava, M. K., Lipsky, E. M., Stanier, C. O., and Robinson, A. L.: Modeling semivolatile organic aerosol mass emissions from combustion systems, Environ. Sci. Technol., 40, 26712677, 2006.

Shrivastava, M. K., Lane, T. E., Donahue, N. M., Pandis, S. N., and Robinson, A. L.: Effects of Gas-Particle Partitioning and Aging of Primary Organic Emissions using the Chemical Transport Model PMCAMx, J. Geophys. Res. A, 113, D18301, doi:10.1029/2007JD009735, 2008.

Simoneit, B. R. T., Elias, V. O., Kobayashi, M., Kawamura, K., Rushdi, A. I., Medeiros, P. M., Rogge, W. F., and Didyk, B. M.: Sugars: Dominant water?soluble organic compounds in soils and characterization as tracers in atmospheric particulate matter, Environ. Sci. Technol., 38, 5939-5949, doi:10.1021/es0403099, 2004.

Smith, G., Woods, E., Baer, T., and Miller, R.: Aerosol uptake described by numerical solution of the diffusion - Reaction equations in the particle, J. Phys. Chem. A, 107, 9582-9587, doi:10.1021/jp021843a, 2003.

Stanier, C. O., Pathak, R. K., and Pandis, S. N.: Measurements of the Volatility of Aerosols from $\alpha$-Pinene Ozonolysis, Environ. Sci. Technol., 41, 2756-2763, doi:10.1021/es0519280, 2007.

Stanier, C. O., Donahue, N. M., and Pandis, S. N.: Parameterization of Secondary Organic Aerosol Mass Fractions from Smog Chamber Data, Atmos. Environ., 42, 2276-2299, doi:10.1016/j.atmosenv.2007.12.042, 2008.

Tolocka, M., Jang, M., Ginter, J., Cox, F., Kamens, R., and Johnston, M.: Formation of oligomers in secondary organic aerosol, Environ. Sci. Technol., 38, 1428-1434, doi:10.1021/es035030r, 2004.

Tsimpidi, A. P., Karydis, V. A., Zavala, M., Lei, W., Molina, L., Ulbrich, I. M., Jimenez, J. L., and Pandis, S. N.: Evaluation of the volatility basis-set approach for the simulation of organic aerosol formation in the Mexico City metropolitan area, Atmos. Chem. Phys., 10, 525-546, doi:10.5194/acp-10-525-2010, 2010.

Ulbrich, I. M., Canagaratna, M. R., Zhang, Q., Worsnop, D. R., and Jimenez, J. L.: Interpretation of organic components from Positive Matrix Factorization of aerosol mass spectrometric data, Atmos. Chem. Phys., 9, 2891-2918, doi:10.5194/acp-9-2891-2009, 2009.

Vaden, T. D., Imre, D., Beránek, J., Shrivastava, M., and Zelenyuk, A.: Evaporation kinetics and phase of laboratory and ambient secondary organic aerosol, P. Natl. Acad. Sci. USA, 108, 21902195, doi:10.1073/pnas.0911206107, 2011.

Virtanen, A., Joutsensaari, J., Koop, T., Kannosto, J., Yli-Pirila, P., Leskinen, J., Makela, J. M., Holopainen, J. K., Pöschl, U., Kulmala, M., Worsnop, D. R., and Laaksonen, A.: An amorphous solid state of biogenic secondary organic aerosol particles, Nature, 467, 824-827, doi:10.1038/nature09455, 2010.

Volkamer, R., Jimenez, J. L., San Martini, F., Dzepina, K., Zhang, Q., Salcedo, D., Molina, L. T., Worsnop, D. R., and Molina, M. J.: Secondary organic aerosol formation from anthropogenic 
air pollution: Rapid and higher than expected, Geophys. Res. Lett., 33, L17811, doi:10.1029/2006GL026899, 2006.

Volkamer, R., Martini, F. S., Molina, L. T., Salcedo, D., Jimenez, J. L., and Molina, M. J.: A missing sink for gas-phase glyoxal in Mexico City: Formation of secondary organic aerosol, Geophys Res. Lett., 34, L19807, doi:10.1029/2007GL030752, 2007.

Weitkamp, E. A., Sage, A. M., Pierce, J. R., Donahue, N. M., and Robinson, A. L.: Organic Aerosol Formation from Photochemical Oxidation of Diesel Exhaust in a Smog Chamber, Environ. Sci. Technol., 41, 6969-6975, doi:10.1021/es070193r, 2007.

Williams, B. J., Goldstein, A. H., Kreisberg, N. M., and Hering, S. V.: In situ measurements of gas/particle-phase transitions for atmospheric semivolatile organic compounds, Proc. Nat. Acad. Sci., 107, 6676-6681, doi:10.1073/pnas.0911858107, 2010.

Yu, J. Z., Cocker, D. R., Griffin, R. J., Flagan, R. C., and Seinfeld, J. H.: Gas-phase ozone oxidation of monoterpenes: Gaseous and particulate products, J. Atmos. Chem., 34, 207-258, 1999.

Zhang, J., Huff Hartz, K. E., Pandis, S. N., and Donahue, N. M.: Secondary Organic Aerosol Formation from Limonene Ozonolysis: Homogeneous and Heterogeneous Influences as a Function of $\mathrm{NO}_{\mathrm{x}}$, J. Phys. Chem. A, 110, 11053-11063, doi:10.1021/jp062836f, 2006.
Zhang, Q., Worsnop, D. R., Canagaratna, M. R., and Jimenez, J. L.: Hydrocarbon-like and oxygenated organic aerosols in Pittsburgh: insights into sources and processes of organic aerosols, Atmos. Chem. Phys., 5, 3289-3311, doi:10.5194/acp-5-32892005, 2005.

Zhang, Q., Jimenez, J. L., Canagaratna, M. R., Allan, J. D., Coe, H., Ulbrich, I., Alfarra, M. R., Takami, A., Middlebrook, A. M., Sun, Y. L., Dzepina, K., Dunlea, E., Docherty, K., DeCarlo, P. F., Salcedo, D., Onasch, T., Jayne, J. T., Miyoshi, T., Shimono, A., Hatakeyama, S., Takegawa, N., Kondo, Y., Schneider, J., Drewnick, F., Borrmann, S., Weimer, S., Demerjian, K., Williams, P., Bower, K., Bahreini, R., Cottrell, L., Griffin, R. J., Rautiainen, J., Sun, J. Y., Zhang, Y. M., and Worsnop, D. R.: Ubiquity and dominance of oxygenated species in organic aerosols in anthropogenically-influenced Northern Hemisphere midlatitudes, Geophys. Res. Lett., 34, L13801, doi:10.1029/2007GL029979, 2007.

Zobrist, B., Marcolli, C., Pedernera, D. A., and Koop, T.: Do atmospheric aerosols form glasses?, Atmos. Chem. Phys., 8, 52215244, doi:10.5194/acp-8-5221-2008, 2008. 